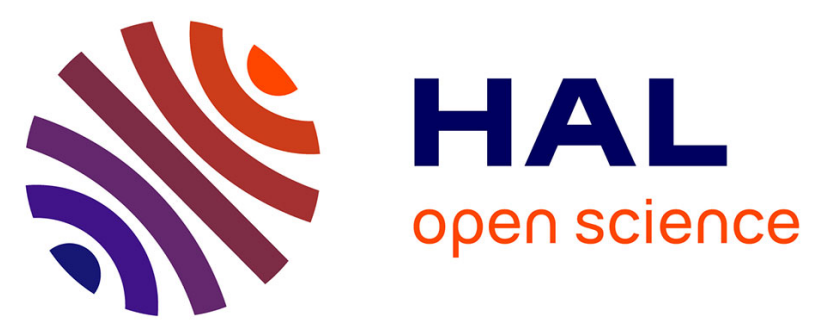

\title{
Activation function 2 (AF-2) of retinoic acid receptor and 9-cis retinoic acid receptor: presence of a conserved autonomous constitutive activating domain and influence of the nature of the response element on AF-2 activity.
}

Beatrice Claude Durand, M Saunders, C Gaudon, B Roy, R. Losson, P. Chambon

\section{To cite this version:}

Beatrice Claude Durand, M Saunders, C Gaudon, B Roy, R. Losson, et al.. Activation function 2 (AF-2) of retinoic acid receptor and 9-cis retinoic acid receptor: presence of a conserved autonomous constitutive activating domain and influence of the nature of the response element on AF-2 activity.. EMBO Journal, 1994, 13 (22), pp.5370-82. hal-02561133

\section{HAL Id: hal-02561133 \\ https://hal.science/hal-02561133}

Submitted on 23 Nov 2020

HAL is a multi-disciplinary open access archive for the deposit and dissemination of scientific research documents, whether they are published or not. The documents may come from teaching and research institutions in France or abroad, or from public or private research centers.
L'archive ouverte pluridisciplinaire HAL, est destinée au dépôt et à la diffusion de documents scientifiques de niveau recherche, publiés ou non, émanant des établissements d'enseignement et de recherche français ou étrangers, des laboratoires publics ou privés. 


\section{Activation function 2 (AF-2) of retinoic acid receptor and 9-cis retinoic acid receptor: presence of a conserved autonomous constitutive activating domain and influence of the nature of the response element on AF-2 activity}

\author{
Béatrice Durand', Michael Saunders², \\ Claudine Gaudon, Bidyut Roy, \\ Régine Losson and Pierre Chambon ${ }^{3}$
}

Institut de Génétique et de Biologie Moléculaire et Cellulaire, CNRS/ INSERM/ULP/Collège de France, BP 163, 67404 Illkirch-cedex, CU de Strasbourg, France

'Present address: MRC Laboratory for Molecular Cell Biology, University College London, Gower Street, London WCIE 6BT, UK ${ }^{2}$ Present address: GLAXO, 25 avenue du Québec, 91951 Les Ulis, France

${ }^{3}$ Corresponding author

Communicated by P.Chambon

A motif essential for the transcriptional activation function 2 (AF-2) present in the $E$ region of retinoic acid receptor (RAR) $\alpha$ and 9-cis retinoic acid receptor (RXR) $\alpha$ has been characterized as an amphipathic $\alpha$-helix whose main features are conserved between transcriptionally active members of the nuclear receptor superfamily. This conserved motif, which can activate autonomously in the absence of ligand in animal and yeast cells, can be swapped between nuclear receptors without affecting the ligand dependency for activation of transcription, thus indicating that a ligand-dependent conformational change is necessary to reveal the AF-2 activation potential within the $E$ region of the nuclear receptor. Interestingly, we show that the precise nature of the direct repeat response element to which RAR/RXR heterodimers are bound can affect the activity of the AF-2s of the heterodimeric partners, as well as the relative efficiency with which all-trans and 9-cis retinoic acids activate the RAR partner.

Key words: dominant negative mutant/ligand-inducible transactivation function/nuclear receptors/response element/retinoid receptors

\section{Introduction}

Nuclear receptors represent a superfamily of transcriptional regulatory proteins that includes the ligand-inducible steroid, thyroid, vitamin D3 and retinoic acid (RA) receptors (Evans, 1988; Green and Chambon, 1988; Gronemeyer, 1991; Laudet et al., 1992) and the so-called orphan receptors (O'Malley and Conneely, 1992). Six regions (A-F; see Figure 1) exhibit different degrees of evolutionary conservation. Region $\mathrm{C}$, the DNA binding domain, is responsible for specific binding to cis-acting response elements (REs). The $\mathrm{E}$ region contains the ligand binding domain, a ligand-dependent transcriptional activation function $2(\mathrm{AF}-2)$ and a dimerization surface composed of conserved heptad repeats (for reviews and references see Forman and Samuels, 1990; Gronemeyer, 1991; Leid et al., 1992a). An autonomous activation function (AF-1) is present in the N-terminal A/B region. Neither of these AFs appears to contain conventional transcriptional activation motifs (for references see Cress and Triezenberg, 1991; Tjian and Maniatis, 1994).

Retinoids are signalling molecules exerting profound effects on vertebrate development, cellular differentiation and homeostasis (for reviews and references see Blomhoff, 1994; Chambon, 1994; Sporn et al., 1994). The all-trans (T-RA) and 9-cis (9C-RA) RA signals are transduced by two families of receptors. Retinoic acid receptor (RAR) $\alpha, \beta$ and $\gamma$ (and their isoforms) are activated by both T-RA and 9C-RA, whereas 9-cis retinoic acid receptor (RXR) $\alpha, \beta$ and $\gamma$ are specifically activated by 9C-RA (for reviews see Leid et al., 1992a; Petkovich, 1992; Kastner et al., 1994; Mangelsdorf et al., 1994). These receptors modulate the expression of their target genes by interacting with RA REs (RAREs). Whereas steroid receptors bind their REs as homodimers (Gronemeyer, 1991, and references therein), RAR/RXR heterodimers bind much more efficiently in vitro than homodimers of either receptor to a number of RAREs (for reviews see Leid et al., 1992a; Stunnenberg, 1993; Kastner et al., 1994; Mangelsdorf et al., 1994). Most of the naturally occurring RAREs consist of the direct repetition (DR) of two core motifs [5'-PuG(G/T)TCA-3'] separated by 5 (DR5), 2 (DR2) or 1 bp (DR1). In addition, RXRs preferentially bind as homodimers to DR1 elements (for references see Giguère, 1994; Zechel et al., 1994). RAR/ RXR heterodimers are also formed in solution both in vitro and in vivo (for references see Nagpal et al., 1993), and were shown to bind and transactivate from different RAREs in cultured cells (Durand et al., 1992). RXRs also heterodimerize with other receptors like thyroid hormone receptors (TRs), vitamin D3 receptor and orphan receptors (reviewed in Green, 1993; Mangelsdorf et al., 1994). The chicken ovalbumin upstream promoter transcription factor (COUP-TF) family includes orphan receptors such as chicken COUP-TF1 (Wang et al., 1991) and its human homologue ear3 (Miyajima et al., 1988), human ear2 (Miyajima et al., 1988), COUP-TFII (Wang et al., 1991) and its human homologue apolipoprotein regulatory protein number 1 (ARP-1; Ladias et al., 1992, and references therein), and seven-up (dSvp), the Drosophila homologue of COUP-TF1 (Segraves, 1994, and references therein). COUP-TF receptors, which bind DNA as homodimers or as heterodimers with RXR, recognize a large panel of REs (Cooney et al., 1993) and have been shown to repress the expression of target genes responding to RARs (Tran et al., 1992; Widom et al., 1992), TRs, vitamin D3 receptor (Cooney et al., 1993), hepatocyte nuclear factor-4 (Ladias et al., 1992; Mietus-Snyter et al., 1992; Nakshatri and 


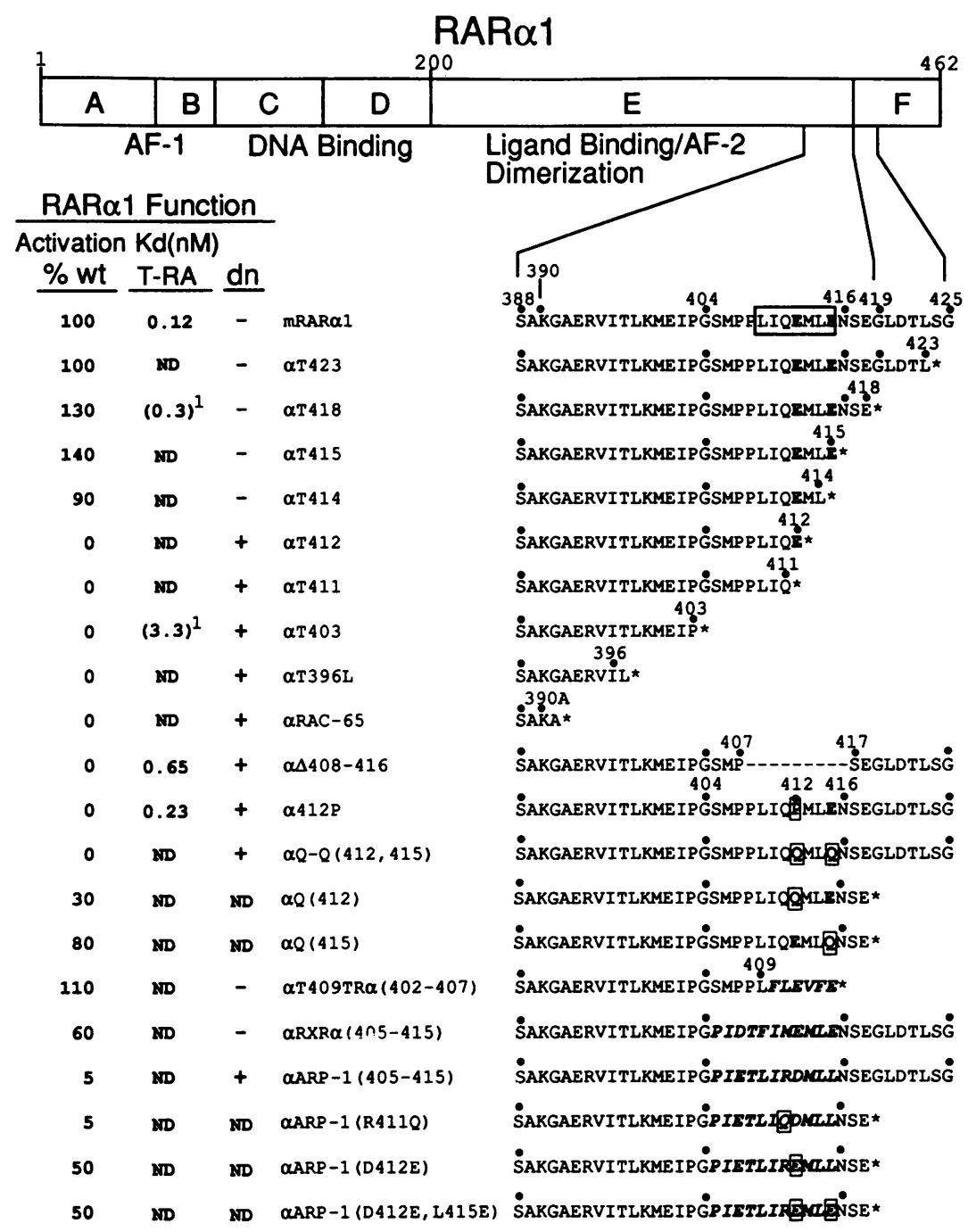

Fig. 1. Structure, dissociation constant for all-trans RA (T-RA), transcriptional and dominant negative activity of C-terminal mutants of mRAR $\alpha 1$. The amino acid sequence (one-letter code) surrounding the border between regions $E$ and F of RAR $\alpha 1$ (amino acids 388-425) is shown and the sequences of individual mutants are indicated (see text and Materials and methods). The endpoints of the truncated mutants are indicated by a star, and the position of the last amino acid residue originated from RAR $\alpha 1$ by a dark point and the corresponding number. The conserved motif (residues $409-415)$ is boxed, and glutamic acid residues 412 and 415 are indicated in bold. The nine amino acid deletion in $\alpha \Delta 408-416$ is indicated by a dashed line; the amino acids derived from the sequences of TR $\alpha$ in $\alpha \mathrm{T} 409 \mathrm{TR} \alpha(402-407)$, from mRXR $\alpha$ in $\alpha \mathrm{RXR} \alpha(405-415)$ and from ARP-1 in $\alpha$ ARP-1(405-415) are in bold. The boundaries prior to and after the deletion or the insertion of a 'foreign' sequence are indicated by a dark point. For each mutant (where appropriate) the percentage of T-RA-dependent activation [compared with wild-type (wt) mRAR $\alpha 1$ ] is indicated, as well as the dominant negative properties of the receptor ( + , dominant negative mutant; ND, non determined). The dissociation constant for T-RA is given in nM. $K_{\mathrm{d}} \mathrm{s}$ were measured by charcoal binding assays (see Materials and methods), except for $\alpha \mathrm{T} 418$ and $\alpha \mathrm{T} 403$ which were taken from Tate $e t$ al. (1994).

Chambon, 1994), peroxisome proliferation activated receptors (PPARs) (Miyata et al., 1993) and oestrogen receptor (ER; Liu et al., 1993), most probably by competing with these nuclear receptors for their DNA binding sites.

RA induces the differentiation of embryonal carcinoma (EC) cell lines. A P19-derived EC cell line, RAC-65, that fails to differentiate in response to T-RA, has been isolated (Pratt et al., 1990); further studies revealed that RAC-65 cells contain a C-terminally truncated 391 amino acidlong RAR $\alpha$ protein (Figure 1, $\alpha$ RAC-65) which behaves as a dominant negative (dn) receptor (Damm et al., 1993, and references therein). We have identified here an amino acid sequence in the C-terminal region of RAR $\alpha$ whose alteration abolishes AF-2 activity in cultured animal cells and yields dominant negative mutant receptors. We demonstrate that dominant negative activity requires the integrity of both the DNA binding and heterodimerization functions of RAR $\alpha$. An activating domain of AF- 2 has been characterized and shown to possess an autonomous transcriptional activity and to be structurally and functionally conserved amongst many members of the nuclear receptor superfamily. We also show that the transactivation potential of the AF-2s of the RAR and RXR heterodimeric partners is dependent on the nature of the RARE to which they are bound.

\section{Results}

\section{Alterations in the C-terminal region of RAR $\alpha$ result} in dominant negative mutants

To delineate the region responsible for the dominant negative activity of the RAC-65 mouse RAR $\alpha 1$ (mRAR $\alpha$; 
A

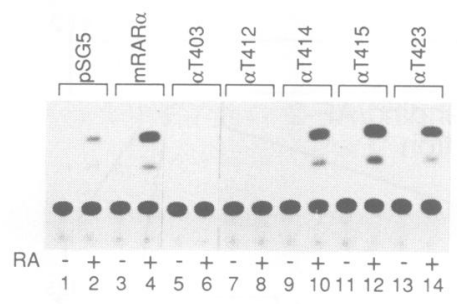

B

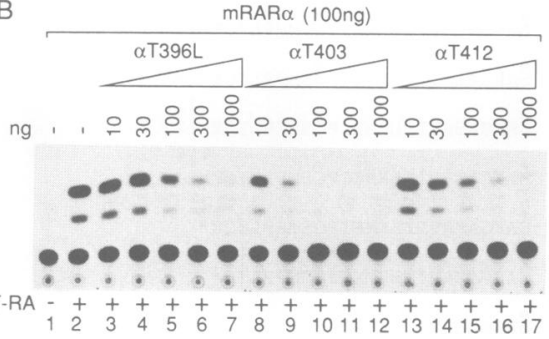

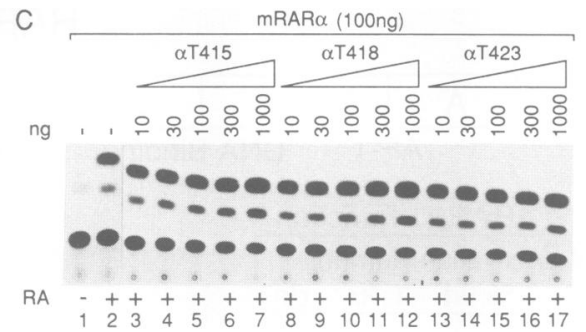

D

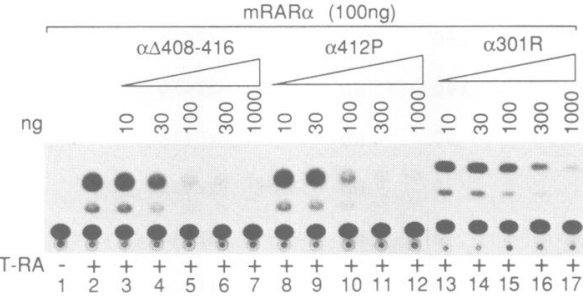

Fig. 2. Transcriptional activation and dominant negative properties of mRAR $\alpha 1$ mutants. (A) T-RA-dependent activation. COS-1 cells were transfected with mRAR $32 / C A T(5 \mu \mathrm{g})$ together with $100 \mathrm{ng}$ of the receptor expression vectors as indicated. (B-D) Dominant negative activity. COS- 1 cells were transfected with mRAR $\beta 2 / C A T(5 \mu \mathrm{g}), 100 \mathrm{ng}$ of mRAR $\alpha 1$ and increasing amounts $(0-1000 \mathrm{ng})$ of the indicated mRAR $\alpha 1$ mutants. (A-D) $100 \mathrm{nM}$ RA were added for 12-15 h as indicated $(+)$. Each experiment has been performed at least three times.

Figure 1, $\alpha \mathrm{RAC}-65)$, a series of C-terminally truncated mutants ( $\alpha \mathrm{T}$ mutants) were constructed and assayed for activation and dominant negative activity in COS-1 cells (Figures 1 and 2, and data not shown; mouse and human $\mathrm{RAR} \alpha 1 \mathrm{E}$ regions are identical in the sequences considered here). COS-1 cells were transfected with a RA responsive reporter containing the mouse RAR 32 promoter (mRARß2/CAT; Smith et al., 1991), and the parental vector pSG5, the mRAR $\alpha 1$ expression vector (designated mRAR $\alpha$ ) or a given $\alpha$ T expression vector. T-RA treatment $(100 \mathrm{nM})$ of cells transfected with pSG5 resulted in a 2.5fold activation (Figure 2A, lanes 1 and 2) due to endogenous RARs. Cells transfected with $\operatorname{mRAR} \alpha$ (100 ng) showed a 15- to 30-fold T-RA-dependent activation (Figure 2A, lanes 3 and 4). The mutants $\alpha \mathrm{T} 423, \alpha \mathrm{T} 418, \alpha \mathrm{T} 415$ and $\alpha \mathrm{T} 414$ similarly activated (Figures 1 and 2A, lanes 9-14, and data not shown). In contrast, no activation was seen with $\alpha \mathrm{T} 412, \alpha \mathrm{T} 411, \alpha \mathrm{T} 403$, and $\alpha \mathrm{T} 396 \mathrm{~L}$ (Figures 1 and 2A, lanes 5-8, and data not shown).

The dominant negative activity of these $\alpha \mathrm{T}$ mutants was then investigated, as indicated in Figure 2B. Any receptor mutant which inhibited activation mediated by mRAR $\alpha$, when present in a 10-fold excess, was defined as dominant negative. $\alpha \mathrm{T} 396 \mathrm{~L}, \alpha \mathrm{T} 403, \alpha \mathrm{T} 412$ (Figure 2B) and $\alpha \mathrm{T} 411$ (data not shown) all acted as dominant negative mutants (Figure 2B, lanes 3-17, compared with lane 2). As observed previously by Damm et al. (1993), $\alpha \mathrm{T} 403$ was much more efficient at inhibiting $\operatorname{mRAR} \alpha$ activity than the other $\alpha \mathrm{T}$ mutants. As expected (Figure 2A), $\alpha \mathrm{T} 414, \alpha \mathrm{T} 415, \alpha \mathrm{T} 418$ and $\alpha \mathrm{T} 423$ (Figure 2C, lanes $3-17$, and data not shown) were not inhibitory.

The region localized between Leu409 and Glu415 of mRAR $\alpha$ (boxed in Figure 1) is well conserved in most members of the receptor family (see below and Figure $3 D$ ). To investigate the importance of this region in RAR $\alpha$, we either deleted amino acids 408-416 ( $\alpha \Delta 408-416$, Figure 1), or altered the structure of this region by replacing Glu412 by a proline residue ( $\alpha 412 \mathrm{P}$, Figure 1$)$. These two mutants did not activate (data not shown), and acted as dominant negative mutants in cotransfection assays (Figure 2D, lanes 3-7 for $\alpha \Delta 408-416$, and lanes $8-12$ for $\alpha 412 \mathrm{P})$.

\section{Efficient dominant negative activity requires both DNA binding and heterodimerization, but not ligand binding}

Using an electrophoretic mobility shift assay and in agreement with previous reports from this and other laboratories (Yu et al., 1991; Leid et al., 1992b; see Introduction), neither mRAR $\alpha, \alpha \Delta 408-416, \alpha 412 \mathrm{P}$ nor any of the $\alpha \mathrm{T}$ mutants translated in vitro efficiently bound the $\beta 2 R A R E$ probe in the absence of RXR (Figure 4A, lanes $1-6$, and data not shown). In contrast, in the presence of $\operatorname{mRXR} \alpha$, equal amounts of mRAR $\alpha$ or of any of the mutated RARs yielded specific shifted complexes of equal intensity corresponding to binding of heterodimers (Figure 4A, lanes 7-11, and data not shown). Thus, none of these dominant negative mutations affect the DNA binding and heterodimerization functions of the mutated proteins.

Three additional mutations were then introduced in either mRAR $\alpha$ ( $\alpha \mathrm{M}$ series) or $\alpha \mathrm{T} 403$ ( $\alpha \mathrm{TM}$ series) to investigate further whether DNA binding and heterodimerization were required for dominant negative activity. Mutation M1 ( $\alpha \mathrm{M} 1$ and $\alpha \mathrm{TM} 1)$, which corresponds to a Cys to Gly substitution at position 88 [Cys residue of the first zinc finger (CI) of the DNA binding domain], has been shown to abolish DNA binding in the case of the glucocorticoid receptor (GR; Freedman et al., 1988). Mutation M2 ( $\alpha \mathrm{M} 2$ and $\alpha \mathrm{TM} 2$ ) corresponds to a Leu to Pro substitution at position 328 (Figure 3B, boxed). Leu328 is one of the hydrophobic residues present in heptad repeat 5, which has been proposed to be part of the dimerization domain (Forman and Samuels, 1990). Mutation M3 ( $\alpha \mathrm{M} 3$ and $\alpha$ TM3) corresponds to the substitution of Met377 (the hydrophobic amino acid present at position 1 of heptad repeat 9) by an arginine residue (Figure 3C, boxed). The corresponding mutation in the mouse oestrogen receptor (mER; Fawell et al., 1990) has 


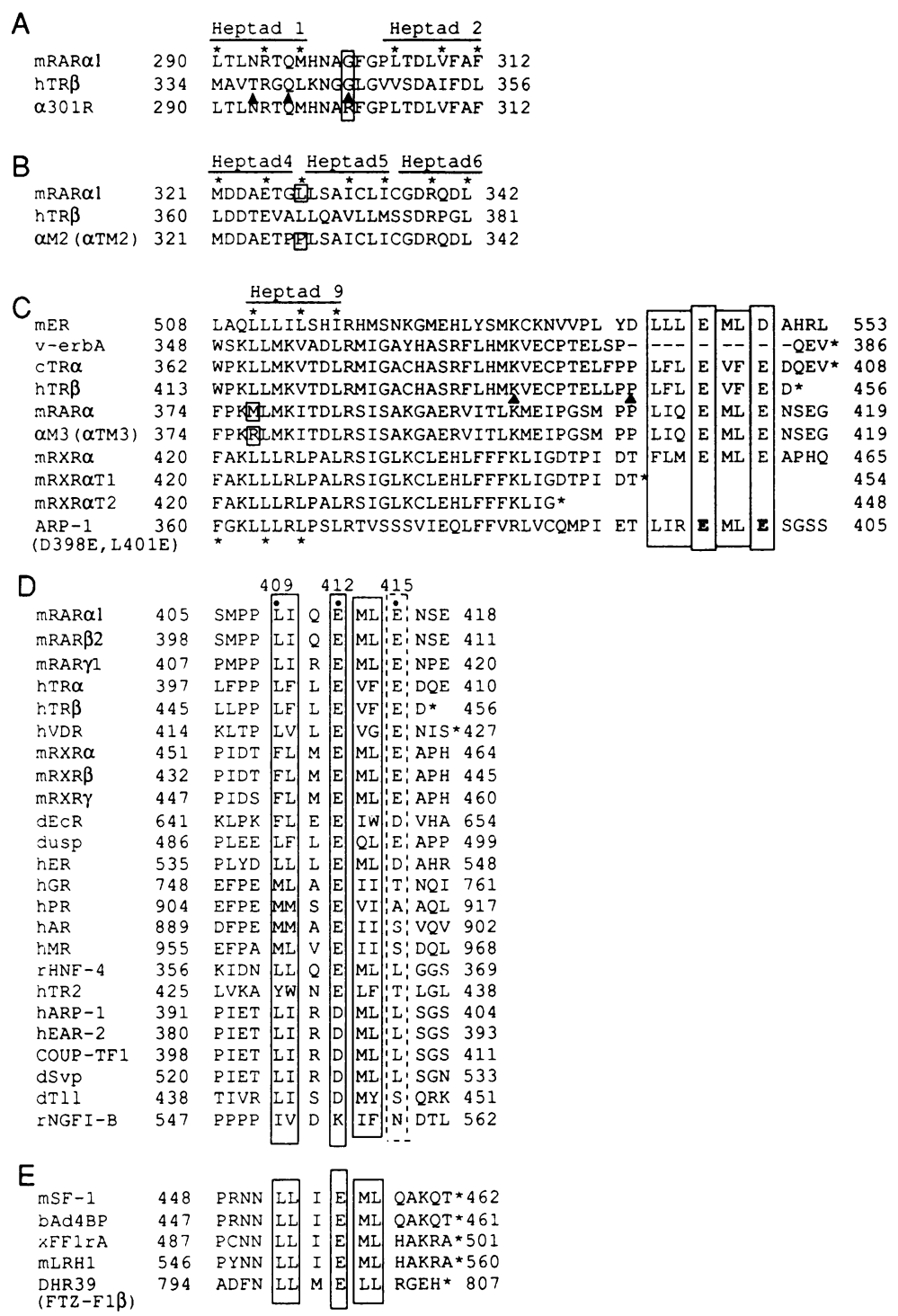

Fig. 3. Sequence alignments of members of the nuclear receptor superfamily. (A) Alignment of amino acid sequences (single-letter code) of heptad repeats 1 and 2 of mRAR $\alpha 1$, hTR $\beta$ and $\alpha 301 R$ mutant. The amino acids at positions 1,5 and 8 of the heptad repeats are indicated by stars. hTR $\beta$ G345, that is mutated to R in a naturally occurring mutation that causes GRTH (Refetoff et al., 1993), and the analogous Gly301 of mRAR $\alpha 1$, that is substituted for an arginine in the dominant negative mutant $\alpha 301 \mathrm{R}$, are boxed. The amino acid positions of naturally occurring mutations found in various GRTH kindreds are indicated by arrowheads $(\Delta \mathrm{T} 337, \mathrm{Q} 340 \mathrm{H}, \mathrm{G} 345 \mathrm{R}$; Refetoff $e$ t al., 1993). (B) Alignment of amino acid sequences of heptad repeats 4-6 of mRAR $\alpha 1, \mathrm{hTR} \beta, \alpha \mathrm{M} 2$ and $\alpha \mathrm{TM} 2$ mutants. Leu328 that is mutated to Pro in mutants $\alpha \mathrm{M} 2$ and $\alpha \mathrm{TM} 2$ is boxed.

(C) Alignment of a number of nuclear receptors showing the amino acid sequences of heptad repeat 9 and of the conserved putative amphipathic $\alpha$ helical region. Note that the amino acid residues at positions 1, 5 and 8 of the heptad repeat 9 , indicated by a star above or below the sequences, are different between steroid/RAR/TR families and members of the RXR and ARP-1 families. Met377 that is mutated to Arg in mutants $\alpha M 3$ and $\alpha \mathrm{TM} 3$ is boxed, as well as the central Glu residue and the two blocks of hydrophobic residues. Terminal amino acids are indicated by stars, where appropriate. The positions of mutated amino acids in GRTH kindreds are indicated by arrowheads (K443E, P453H; Refetoff et al., 1993). The deletion in v-erbA is indicated by a dashed line. The sequences of mRXR $\alpha \mathrm{T} 1, \mathrm{mRXR} \alpha \mathrm{T} 2$ and ARP-1(D398E,L401E) (where the two mutated amino acids are in bold) are given. (D) Sequence alignment of the putative amphipathic helices of several members of the nuclear receptor superfamily. The central conserved acidic amino acid and the two pairs of hydrophobic amino acids are boxed, whereas the second less conserved acidic amino acid is boxed in a dashed line. Leu409. Glu412 and Glu415 correspond to mRAR $\alpha 1$. Terminal amino acids are indicated by a star, where appropriate. m, mouse; h, human; d, D.melanogaster; r, rat; b, bovine; x, Xenopus. RARs (retinoic acid receptors), TR $\alpha$ (thyroid hormone receptor $\alpha$ ), TR $\beta$ (thyroid hormone receptor $\beta$ ), VDR (vitamin D3 receptor), RXRs (9-cis retinoic acid receptors; Leid et al., 1992b), EcR (ecdysone receptor; Koelle et al., 1991), usp (ultraspiracle), ER (oestrogen receptor), GR (glucocorticoid receptor), PR (progesterone receptor), AR (androgen receptor), MR (mineralocorticoid receptor), HNF-4 (hepatocyte nuclear factor-4), hTR2 (thyroid receptor 2), ARP-1 (apolipoprotein regulatory protein number 1), EAR-2 (erbA-related 2; Miyajima et al., 1988), COUP-TF1 (Miyajima et al., 1988), Svp (seven-up), TIl (tailless), NGFI-B (nur77/N10; Paulsen et al., 1992; Davis et al., 1993, and references therein). (E) Sequence alignment of the AF-2 activating domain of members of the FTZ-F1 receptor family. The endpoint of the receptor is indicated by a star. mSF-1 (mouse steroidogenic factor 1; Ikeda et al., 1993), bAd4BP (bovine Ad4 binding protein), xFF1rA (Xenopus FTZ-F1-related receptor 1; Ellinger-Ziegelbauer et al., 1994), mLRH1 (mouse liver receptor homologous protein 1; Genbank accession number M81385), DHR39 [D.melanogaster hormone receptor 39, also called FTZ-F1 $\beta$ (Fushi tarazu type 1ß)]. (For references see Gronemeyer, 1991; Lazar, 1993; Chambon, 1994; Segraves, 1994.) 


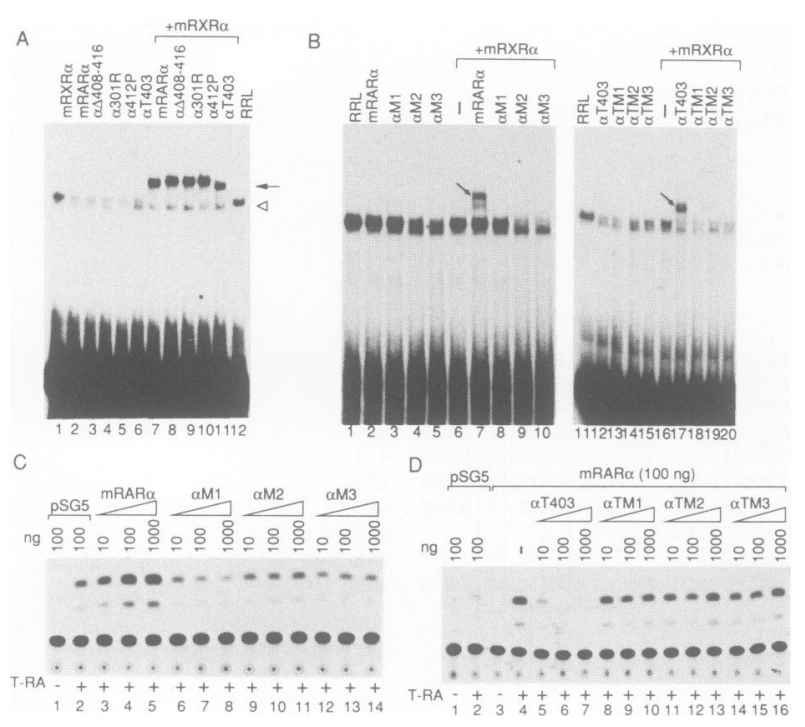

Fig. 4. DNA binding of mutated RARs is required for strong dominant negative activity. (A and $\mathbf{B}$ ) Gel retardation assays are shown where in vitro-translated $\mathrm{mRAR} \alpha 1$ and indicated receptor mutants are incubated alone (A, lanes 1-6; B, lanes 2-5 and 12-15) or coincubated with in vitro-translated $\mathrm{mRXR} \alpha$ (A, lanes 7-11; B, lanes 6-10 and $16-20)$ in the presence of a ${ }^{32} \mathrm{P}$-labelled $\beta 2 \mathrm{RARE}$ oligonucleotide probe (upper strand, 5'-TCGAGGGTAGGGTTCACCGAAAGTTCACTCG- $\left.3^{\prime}\right)$. Specific complexes are marked with an arrow, non-specific complexes by an open arrowhead. RRL (lane 12), control assay with an unprogrammed rabbit reticulocyte lysate. (C and D) Transactivation by DNA binding-deficient mutants $\alpha \mathrm{M} 1, \alpha \mathrm{M} 2$ and $\alpha \mathrm{M} 3$, and dominant negative properties of DNA binding-deficient mutants $\alpha \mathrm{TM} 1, \alpha \mathrm{TM} 2$ and $\alpha \mathrm{TM} 3$. COS-1 cells were transfected with mRAR $32 / C A T(5 \mu \mathrm{g})$ and either (C) the indicated amounts (in ng) of pSG5, mRAR $\alpha 1$ and the $\alpha \mathrm{M}$ series of mutant receptors or (D) mRAR $\alpha 1$ (100 ng) and increasing amounts $(0-1000 \mathrm{ng})$ of either $\alpha \mathrm{T} 403, \alpha \mathrm{TM} 1, \alpha \mathrm{TM} 2$ or $\alpha \mathrm{TM} 3.100 \mathrm{nM}$ T-RA were added for $15 \mathrm{~h}$ where indicated $(+)$.

been shown to prevent its homodimerization. Upon the addition of $\operatorname{RXR} \alpha$, only $\operatorname{mRAR} \alpha$ and $\alpha \mathrm{T} 403$ bound the DNA probe (Figure 4B, lanes 7 and 17, arrows), whereas $\alpha \mathrm{M} 1, \alpha \mathrm{M} 2$ and $\alpha \mathrm{M} 3$ (Figure $4 \mathrm{~B}$, lanes $8-10$ ) or $\alpha \mathrm{TM} 1$, $\alpha \mathrm{TM} 2$ and $\alpha$ TM3 (lanes 18-20) did not bind, indicating that the integrity of heptads 5 and 9 is required for RAR/ RXR heterodimerization. Cotransfection of increasing amounts of mRAR $\alpha$ caused a clear increase in liganddependent activation of mRAR $32 / C A T$ (Figure $4 \mathrm{C}$, lanes $3-5)$, whereas cotransfection of the $\alpha \mathrm{M} 1, \alpha \mathrm{M} 2$ and $\alpha \mathrm{M} 3$ did not result in any increase, in agreement with the inability of these mutants to bind DNA (Figure 4C, lanes 6-14). In contrast, Au-Fliegner et al. (1993) reported that a human RAR $\alpha$ mutant, apparently identical to our $\alpha \mathrm{M} 3$ mutant (M377R), stimulated transcription in cotransfection assays. The reason for this discrepancy is unknown, but may be related to differences in assay conditions $\left[10^{-6}\right.$ M T-RA for $40 \mathrm{~h}$ in the case of Au-Fliegner et al. (1993), under conditions where T-RA is known to be converted to 9C-RA (Levin et al., 1992), instead of $10^{-7} \mathrm{M}$ RA for $12-15 \mathrm{~h}$ in our case]. In this respect we also note that Au-Fliegner et al. (1993) reported that their M377R mutant heterodimerized in vitro with RXR in the presence, but not in the absence, of $10^{-6} \mathrm{M}$ T-RA. Interestingly, activation by endogenous RARs was decreased upon cotransfection of 100 and $1000 \mathrm{ng}$ of $\alpha \mathrm{M} 1$, the mutant which carries the $\mathrm{CI}$ zinc finger mutation (Figure 4C, compare lanes 7 and

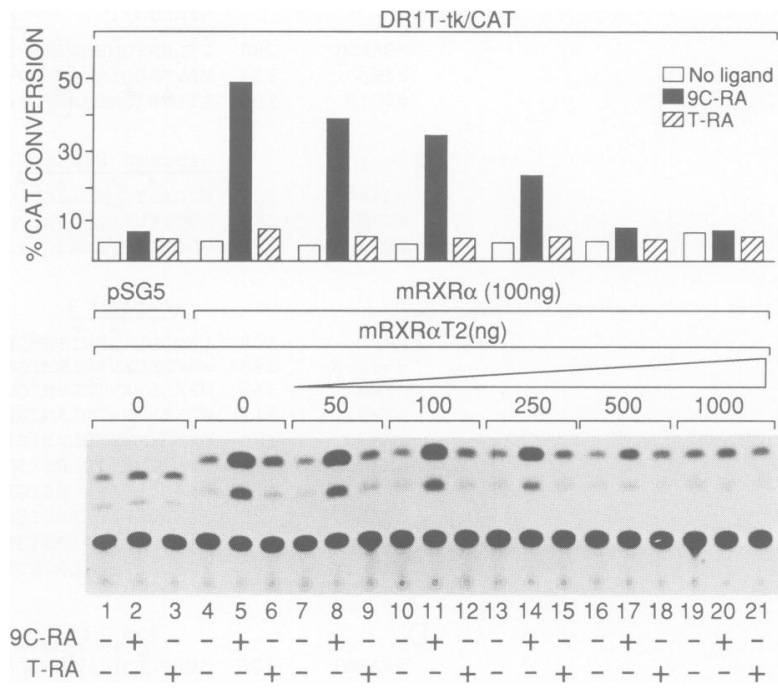

Fig. 5. Characterization of a dominant negative mutation of $\operatorname{mRXR} \alpha$. COS- 1 cells were transfected with DR1T-tk/CAT $(2 \mu \mathrm{g}$; see text) and either pSG5 or the $\mathrm{mRXR} \alpha$ expression vector (100 $\mathrm{ng}$ ). Increasing amounts (0-1000 ng) of mRXRdn (corresponding to mRXR $\alpha \mathrm{T} 2$ of Figure $3 \mathrm{C}$ ) were cotransfected with $\operatorname{mRXR} \alpha(100 \mathrm{ng})$. Cells were treated with vehicle (ethanol) $(-)$, T-RA $(50 \mathrm{nM})$ or 9C-RA $(50 \mathrm{nM})$ as indicated. A representative CAT assay and graphs corresponding to average values measured by scintillation counting from three independent experiments are shown.

8 with lane 2). Cotransfection of increasing amounts of cotransfected $\alpha \mathrm{T} 403$ progressively extinguished the activation by mRAR $\alpha$ (Figure 4D, lanes 5-7, compare with lane 4), whereas no decrease was observed when $\alpha \mathrm{TM} 1, \alpha \mathrm{TM} 2$ or $\alpha \mathrm{TM} 3$ were cotransfected (Figure $4 \mathrm{D}$, lanes 8-16), even at the highest level (1000 ng). However, similar to the $\alpha \mathrm{M} 1$ mutant (see above), high levels (1000 ng) of $\alpha \mathrm{TM} 1$ transfected alone slightly inhibited activation by endogenous RARs, whereas $\alpha$ TM 2 and $\alpha$ TM 3 did not (data not shown). Thus, the integrities of both the DNA binding domain and the dimerization surface are required for efficient dominant negative activity.

We next investigated whether ligand binding was mandatory for dominant negative activity. In the dominantly inherited syndrome of generalized resistance to thyroid hormones (GRTH syndrome; reviewed in Refetoff et al., 1993), the TR $\beta$ dominant negative mutants are mutated in either the $\mathrm{N}$ - (Figure 3A; $\Delta \mathrm{T} 337, \mathrm{Q} 340 \mathrm{H}, \mathrm{G} 345 \mathrm{R}$ ) or C-terminal (Figure 3C; K443E, P453H) part of region $\mathrm{E}$ (Refetoff et al., 1993, and references therein). By analogy with the hTR $\beta$ G345R dominant negative mutant which has lost its ability to bind T3 (Refetoff et al., 1993), we substituted Gly 301 in $\operatorname{mRAR} \alpha$ with an arginine residue (Figure 3A, $\alpha 301 \mathrm{R}$ ). $\alpha 301 \mathrm{R}$ behaved as a dominant negative mutant (Figure 2D, lanes 13-17). RA binding to bacterially expressed mRAR $\alpha$, and to $\alpha 412 \mathrm{P}, \alpha \Delta 408-416$ and $\alpha 301 \mathrm{R}$ dominant negative mutants, was determined using a dextran-coated charcoal absorption assay. mRAR $\alpha$, $\alpha 412 \mathrm{P}$ and $\alpha \Delta 408-416$ bound $\left[{ }^{3} \mathrm{H}\right] \mathrm{RA}$, whereas $\alpha 301 \mathrm{R}$ did not (Figure 1 and data not shown); $\alpha 412 \mathrm{P}$ and $\alpha \Delta 408$ 416 reproducibly had a 2 - and a 5 - to 6-fold reduced affinity for T-RA, respectively (Figure 1). From all of these results, we conclude that DNA binding and heterodimerization, but not ligand binding, are required for dominant negative activity. 


\section{RXR dominant negative mutations}

We tested two C-terminal deletion mutants of mouse $\mathrm{RXR} \alpha, \mathrm{mRXR} \alpha \Delta 455-466(\mathrm{mRXR} \alpha \mathrm{T} 1)$ and $\mathrm{mRXR} \alpha \Delta$ 449-466 (mRXR $\alpha \mathrm{T} 2)$ (Figure 3C; Leid et al., 1992b). These mutants, which are known to bind DNA as homodimers or as heterodimers with RARs (Leid et al., 1992b), were cotransfected with DR1T-tk/CAT which contains a DR1T RE (see below) and has been shown to be transactivated upon $\mathrm{RXR} \alpha$ cotransfection (Figure 5; Mader et al., 1993b). Transfection of COS-1 cells with $100 \mathrm{ng} \mathrm{mRXR} \alpha$ yielded a strong activation in the presence of $50 \mathrm{nM} 9 \mathrm{C}$ RA, with very little activation with $50 \mathrm{nM}$ T-RA (Figure 5 , lanes 4-6), in agreement with previous results showing that RXRs are not activated at $50 \mathrm{nM}$ T-RA (Durand et al., 1992). Cotransfection of $\mathrm{mRXR} \alpha$ and increasing amounts of mRXR $\alpha \mathrm{T} 2$ (50-1000 ng; Figure 5, lanes 721) reduced activation of the reporter (Figure 5, lanes 8 , $11,14,17$ and 20), indicating that $\mathrm{mRXR} \alpha \mathrm{T} 2$ is a dominant negative mutant, and that $\operatorname{mRXR} \alpha$ was responsible for the observed activation. mRXR $\alpha \mathrm{T} 1$ exhibited similar dominant negative properties (data not shown).

\section{Characterization of an activating domain in the $C$ - terminal part of the $E$ region}

The mRAR $\alpha 1$ motif located between amino acids 409 and 415 is conserved in many members of the nuclear receptor family including several insect receptors (Zenke et al., 1990; Koelle et al., 1991; Danielan et al., 1992; Figure 3D and E). The main features of this motif are a central acidic amino acid residue [Glu, with the exceptions of Asp in the case of the COUP-TF family (including dSvp) and Drosophila tailless (dTll), and Lys in the case of nur77/N10 (NGFI-B); Figure 3D], flanked by two pairs of hydrophobic residues (Figure 3D). In the case of the RAR and TR families, two proline residues precede this motif, which can be predicted to form an amphipathic $\alpha$ helical structure (Zenke et al., 1990). That the Glu residues 412 and 415 in mRAR $\alpha 1$ are the only amino acids of this helix to be conserved in all members of the RAR, RXR and TR families (Figure 3D), suggested to us that they could be important for transactivation. The RAR $\alpha 1$ mutant $\alpha \mathrm{Q}-\mathrm{Q}(412,415)$ (Figure 1), in which these Glu residues were replaced by Gln residues, did not transactivate mRAR $32 / C A T$ (Figure 6A, lanes 11 and 12, and C, lanes 7 and 8) and behaved as a dominant negative mutant (Figure 6B, lanes 8-12). The replacement of Glu412 by a Gln residue decreased transactivation by $\sim 70 \%[\alpha \mathrm{Q}(412)$; Figures 1 and $6 \mathrm{C}$, lane 6], whereas mutant $\alpha \mathrm{Q}(415)$ transactivated with $\sim 80 \%$ of RAR $\alpha$ wild-type efficiency, indicating that both Glu residues are required for optimal activation. Chimeric receptors between RAR and either TR, RXR or ARP-1 were constructed (Figure 1). Amino acids $410-415$ of $\alpha \mathrm{T} 415$ were replaced by the corresponding TR $\alpha$ residues [ $\alpha \mathrm{T} 409 \mathrm{TR} \alpha(402-407)]$, and residues $405-415$ of RAR $\alpha 1$ were replaced by those of either $\operatorname{RXR} \alpha[\alpha \operatorname{RXR} \alpha(405-415)]$ or ARP-1 [ $\alpha \mathrm{ARP}-1(405-$ 415)] (Figure 1). $\alpha$ T409TR $\alpha(402-407)$ transactivated in the presence of T-RA at least as efficiently as RAR $\alpha$ (Figure 6A, compare lane 6 with lane 4), whereas $\alpha \mathrm{RXR} \alpha(405-415)$ was slightly less efficient than RAR $\alpha$ [60\% of mRAR $\alpha$ activation; Figure 6A, compare lane 8 with lane 4; similar data (not shown) were obtained in the presence of $9 \mathrm{C}-\mathrm{RA}]$. In marked contrast, $\alpha \mathrm{ARP}-$
1(405-415) did not efficiently stimulate (Figure 6A, lanes 9 and 10, and C, lanes 9 and 10) and behaved as a dominant negative mutant (Figure 6B, lanes 3-7); note, however, that a residual T-RA-dependent activation $(\sim 5 \%$ of wild-type RAR $\alpha 1$ ) was repeatedly observed in the presence of $\alpha$ ARP-1(405-415) (Figure 6B, compare lanes 5-7 with lanes 10-12), suggesting that this chimera possesses a weak activation function. The conversion of ARP-1 Asp398, or of both Asp398 and Leu401 (Figure $3 \mathrm{D})$, into Glu residues in the $\alpha$ ARP-1(405-415) chimera generated receptors $[\alpha \mathrm{ARP}-1(\mathrm{D} 412 \mathrm{E})$ and $\alpha \mathrm{ARP}-$ 1(D412E,L415E), respectively; see Figure 1], which activated almost as efficiently as the $\alpha \mathrm{RXR} \alpha(405-415)$ chimera (Figures 1 and 6C, lanes 14 and 16 compare with lane 18), thus confirming the critical role of RAR $\alpha$ Glu412 in activation. Note also that conversion of Arg411 into a Gln residue (as it is in RAR $\alpha$ ) in the $\alpha$ ARP-1(405-415) chimera had no effect on transactivation efficiency [Figures 1, $\alpha$ ARP-1(R411Q), and 6C, lane 12].

The same D398E and L401E mutations were also made in full-length ARP-1 [Figure 3C, ARP-1(D398E,L401E)] to investigate whether ARP-1 could be transformed from a repressor into an activator. COS-1 cells were transfected with ARP-1(D398E,L401E) with mCRBPII/CAT or DR1G-tk/CAT, which possess either the promoter sequence of the mouse CRBPII gene (Nagpal et al., 1993; Nakshatri and Chambon, 1994) or a DR1G-tk promoter (Mader et al., 1993a; see below). Both have been shown previously to contain DNA elements which can efficiently bind ARP-1 or RXRs (Ladias et al., 1992; Nakshatri and Chambon, 1994). Interestingly, these reporters were not activated by ARP-1(D398E,L401E) under conditions where RXR $\alpha$ efficiently activated (data not shown). It should be stressed that ARP-1(D398E,L401E) contains in the ARP-1 context exactly the same sequence (PIETLIREMLE) which, in the RAR $\alpha$ context [ $\alpha$ ARP1(D412E,L415E)], results in an efficient activator (Figure 1).

The above results indicate that the conserved motif is not sufficient to bring about activation within the ARP-1 context, but do not exclude that it could constitute an activating domain on its own. Thus, Gal4-RAR $\alpha(404$ $418)_{3}$, containing a trimeric repeat of the conserved motif of RAR $\alpha 1$ fused to the DNA binding domain of the yeast transactivator Gal4 [Gal(1-147)], was constructed and transfected with 17M5-G/CAT containing five repeats of the DNA binding site of Gal4 (17mer) inserted upstream of the $\beta$-globin promoter and the CAT gene (Webster et al., 1988). A reproducible $\sim 4$-fold ligand-independent activation of the reporter was observed (Figure 6D, compare lane 1 with lane 2). Two additional chimeric proteins containing the DNA binding domain of the ER [amino acid residues 176-282, ER(C)], which fused to either residues 390-462 of mRAR $\alpha$ [ER(C)RAR $\alpha(390-462)$ ] or residues 436-467 of $\operatorname{mRXR} \alpha$ [ER(C)RXR $\alpha(436-467)$ ], were transfected with (ERE) $)_{2}$-tk/CAT containing two EREs in front of the tk/CAT reporter. As controls, we used either ER(C)RAR( - ) (see Materials and methods) or a derivative of ER(C)RAR $\alpha(390-462)$ harbouring the two mutations $\mathrm{E} 412 \mathrm{Q}$ and E415Q in the conserved motif [referred to in Figure $6 \mathrm{E}$ as $\mathrm{ER}(\mathrm{C}) \mathrm{RAR} \alpha(\mathrm{E} 412 \mathrm{Q}, \mathrm{E} 415 \mathrm{Q})]$. A reproducible $\sim 4$-fold stimulation of (ERE) ${ }_{2}$-tk/CAT activity was observed upon cotransfection of $\operatorname{ER}(C) \operatorname{RAR} \alpha(390-462)$ 


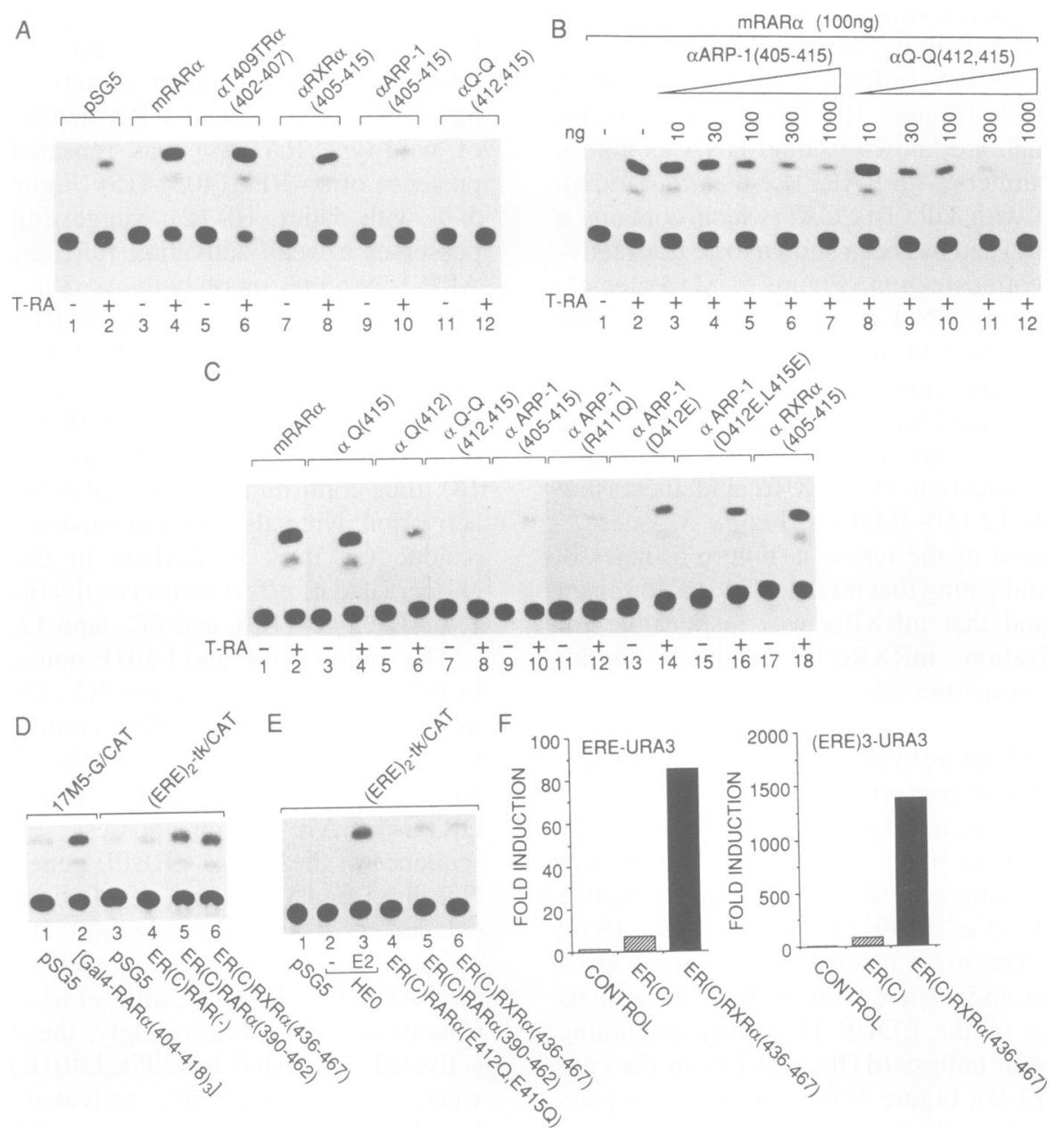

Fig. 6. Transcriptional activation and dominant negative properties of mutant and chimeric receptors derived from $\alpha$ T409TR $\alpha(402-407)$, $\alpha \mathrm{RXR} \alpha(405-415), \alpha \mathrm{ARP}-1(405-415), \alpha \mathrm{Q}-\mathrm{Q}(412,415)$ and AF-2 activating domain on its own. (A-C) T-RA-dependent activation properties of $\alpha \mathrm{T} 409 \mathrm{TR} \alpha(402-407), \alpha \mathrm{RXR} \alpha(405-415), \alpha \mathrm{ARP}-1(405-415), \alpha \mathrm{Q}-\mathrm{Q}(412,415)$ and receptor mutants derived from $\alpha \mathrm{ARP}-1(405-415)$ and $\alpha \mathrm{Q}-\mathrm{Q}(412,415)$ and dominant negative properties of $\alpha \mathrm{ARP}-1(405-415)$ and $\alpha \mathrm{Q}-\mathrm{Q}(412,415)$ receptors. COS-1 cells were transfected with mRAR $\beta 2$ / CAT $(5 \mu \mathrm{g})$, together with $100 \mathrm{ng}$ of receptor expression vector as indicated (A and C), or $100 \mathrm{ng}$ of mRAR $\alpha 1$ expression vector and increasing concentrations $(0-1000 \mathrm{ng})$ of either $\alpha \mathrm{ARP}-1(405-415)$ or $\alpha \mathrm{Q}-\mathrm{Q}(412,415)(\mathrm{B})$. Cells were treated with T-RA at $100 \mathrm{nM}$ for $15 \mathrm{~h}$ as indicated. (D and E) Transactivation capacity of AF-2 activating domain on its own. COS-1 cells were transfected with either the 17M5-G/CAT (1 $\mu \mathrm{g})$ or the $(\mathrm{ERE})_{2}$-tk/CAT $(1 \mu \mathrm{g})$ reporter gene together with either pSG5, Gal4-RAR(404-416) 3 (500 ng), ER(C)RAR(-) (500 ng), ER(C)RAR(390-462) (500 ng), ER(C)RXR(436-467) (500 ng) (D), or hER (HEO) [in the absence or presence of $10^{-8} \mathrm{M}$ oestradiol (E2) for 15 h], ER(C)RAR(E412Q, $\mathrm{E} 415 \mathrm{Q})(500 \mathrm{ng}$ ) (E) [the difference in spot intensity between (D) lanes 5 and 6 and (E) lanes 5 and 6 is due to a difference in time exposure]. (F) A 2mer-derived yeast multicopy vector YEp90 expressing $\operatorname{ER}(C), \operatorname{ER}(C) \operatorname{RXR} \alpha(436-467)$ or no protein (control) was introduced into the yeast reporter strains PL1 and PL3, containing a chromosomally integrated URA3 reporter gene regulated by one or three oestrogen response elements, respectively. Reporter gene activities were determined by measuring the specific activity of the URA3 gene product orotidine-5'-monophosphate decarboxilase (OMPdecase). Activities in cell-free extracts were measured as described in Pierrat $e$ t al. (1992) and are represented as fold induction over the basal reporter gene expression level exhibited by the control. At least three individual yeast transformants were assayed for each sample.

or $\operatorname{ER}(\mathrm{C}) \mathrm{RXR} \alpha(436-467)$ (Figure 6D, lanes 3-6 and E, compare lane 4 with lanes 5 and 6 ; for comparison, note in Figure $6 \mathrm{E}$ that the full-length ER expression vector HEO resulted in an $\sim 5$-fold stronger activation).

The ability of the conserved motif to function as an autonomous activating domain was also investigated in yeast. Yeast cells which contain one or three EREs in front of the URA3 reporter gene [ERE-URA3 and (ERE)3URA3; Pierrat et al., 1992] were transformed with vectors encoding $\operatorname{ER}(\mathrm{C})$ or $\mathrm{ER}(\mathrm{C}) \mathrm{RXR} \alpha(436-467)$. $\quad \mathrm{ER}(\mathrm{C})$ RXR $\alpha(436-467)$, but not $\operatorname{ER}(C)$, strongly activated expression of the URA3 reporter genes (80- and 1300fold, Figure 6F). A chimeric protein LexA-RXR $\alpha(436-$ 467 ), containing the conserved motif of $R X R \alpha$ fused to the LexA DNA binding domain (amino acids 1-211), was also a strong activator in yeast (data not shown).

\section{Response element and promoter context dependence of the activation potential of the AF-2 function of RAR and RXR}

We have shown (Durand et al., 1992) that RAR $\alpha \mathrm{T} 412$ and RXR $\alpha \mathrm{T} 1$ (designated in our previous study and below as mRARdn and mRXRdn, respectively) act by competing with wild-type RAR and RXR, respectively, during the formation of RAR/RXR heterodimers. Since the liganddependent AF-2 is abrogated in these dominant negative mutants, we used them here as tools to investigate whether the activities of RAR and RXR AF-2s could depend on 

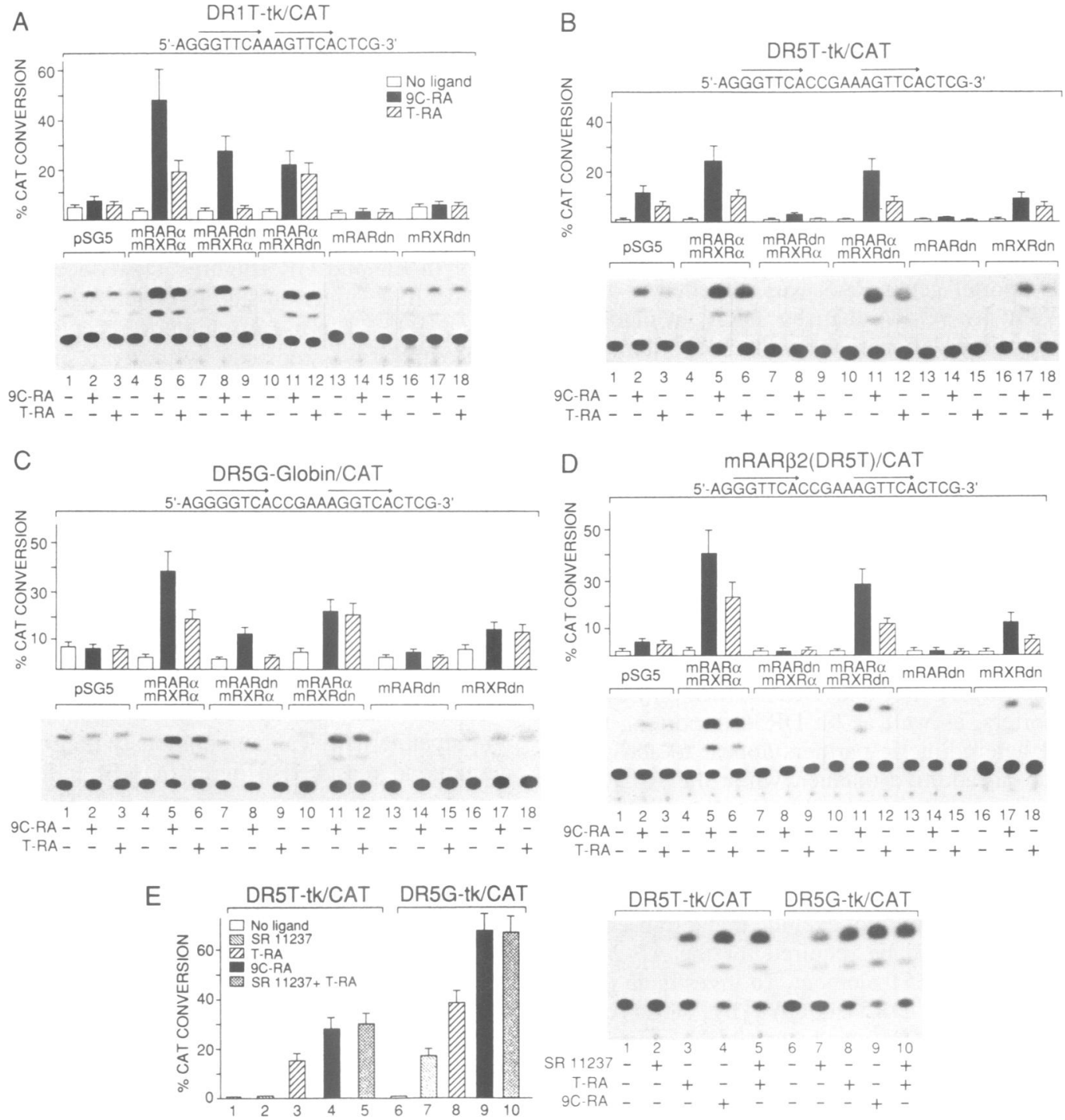

Fig. 7. The AF-2s of RAR and RXR heterodimeric partners have different transactivation potentials depending on the response element. (A-D) COS-1 cells were transfected with $2 \mu \mathrm{g}$ of DR1T-tk/CAT (A), $2 \mu \mathrm{g}$ of DR5T-tk/CAT (B), $2 \mu \mathrm{g}$ of DR5G-globin/CAT (C) or $5 \mu \mathrm{g}$ of mRAR $32 / C A T$ (D) with $250 \mathrm{ng}$ of $\mathrm{mRAR} \alpha, \mathrm{mRXR} \alpha, \mathrm{mRARdn}(\alpha \mathrm{T} 412)$ and $\mathrm{mRXRdn}(\mathrm{mRXR} \alpha \mathrm{T} 2)$ as indicated. In all cases the upper strand of the responsive element is indicated. Cells were treated with either ethanol vehicle (-), $50 \mathrm{nM}$ 9-cis RA (9C-RA), or $50 \mathrm{nM}$ all-trans RA (T-RA) for 12-15 h; CAT activity was determined. (E) HeLa cells were transfected with $5 \mu \mathrm{g}$ of DR1T-tk/CAT or $5 \mu \mathrm{g}$ of DR5G-tk/CAT, as indicated. Cells

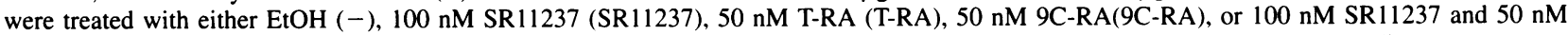
T-RA (SR11237 + T-RA) for 12-15 h; CAT activity was determined. (A-E) Representative CAT assays and graphs corresponding to average values of several independent experiments are shown.

the nature or the spacing of the response elements on which they are bound and on the promoter context (Durand et al., 1992). COS-1 cells were transfected with DR1Ttk/CAT (Figure 7A, DR1T), DR1G-tk/CAT (DR1G, 5'AGGGGTCAAAGGTCACTCG-3'; data not shown), DR5T-tk/CAT (Figure 7B, DR5T), DR5G-globin/CAT (Figure 7C, DR5G), DR5G-tk/CAT (data not shown) or mRARß2(DR5T)/CAT (Figure 7D), together with vectors encoding $m R A R \alpha 1, m R X R \alpha, m R A R d n$ or $m R X R d n$ alone or in various combinations. A total of $50 \mathrm{nM} 9 \mathrm{C}-\mathrm{RA}$ or $50 \mathrm{nM}$ T-RA were added for $12 \mathrm{~h}$, under conditions where RAR AF-2 is activated by both T-RA and 9C-RA, whereas RXR AF-2 is activated by 9C-RA alone (Durand et al., 1992, and references therein). With DR1T-tk/CAT, T-RA activates transcription to the same extent in the presence of mRAR and mRXRdn, as in the presence of mRAR and
mRXR wild-type (Figure 7A, compare lane 12 with lane 6); furthermore, cotransfection of mRXR and mRARdn resulted in a 9C-RA-dependent RXR activity which corresponded to the difference between the T-RA- and 9C-RAdependent activities observed when mRAR and mRXR were transfected together (Figure 7A, compare lanes 7-9 with lanes 4-6). Since similar results were obtained with DR1G-tk/CAT (data not shown), we conclude that, in agreement with our previous results (Durand et al., 1992), the AF-2s of RAR and RXR bound as heterodimeric partners to DR 1 elements may act independently of one another and in an additive fashion. Furthermore, RAR was as efficiently activated by T-RA as by $9 \mathrm{C}-\mathrm{RA}$ (Figure $7 \mathrm{~A}$, lanes 11 and 12), whereas as expected RXR was selectively activated by 9 C-RA (Figure 7A, lanes 8 and 9 ).

Similar transfection experiments were then performed 
using DR5T-tk/CAT and mRAR $\beta 2$ (DR5T)/CAT (the natural mouse RAR $\beta 2$ promoter; Figure $7 \mathrm{~B}$ and $\mathrm{D}$ ). Cotransfection of mRARdn with $\mathrm{mRXR} \alpha$ decreased the expression of DR5T-tk/CAT and mRAR $\beta 2 / C A T$ to levels even lower than those seen with endogenous receptors (Figure 7B and D, compare lanes 7-9 with lanes 1-3; see also mRARdn on its own in lanes 13-15). In contrast, transfection of RAR with RXRdn instead of RXR only moderately decreased activation by either T-RA or 9C-RA (compare lanes 4-6 with lanes 10-12). Most interestingly, on both DR5T reporter genes RAR was activated to a 2fold greater extent by $9 \mathrm{C}-\mathrm{RA}$ than by T-RA, in marked contrast with the observation made with DR1 elements (Figure 7A, B and D, compare lanes 10-12). To investigate whether these differences between DR 1 and DR5 reporters were dependent on the spacing of the directly repeated motifs, on the sequence of the response element and/or on the promoter context, additional transfections were carried out with either DR5G-tk/CAT (data not shown) or DR5G-globin/CAT (Figure 7C). Strikingly, the activation profiles were very similar to those obtained with DRIT or DR 1G reporters (compare Figure 7A with C), indicating that with both of these DR5G reporters, AF-2s of RAR and RXR were active and additive, and that RAR was similarly activated by $9 \mathrm{C}-\mathrm{RA}$ and T-RA. Thus, on DR1T and DR 1G reporters, as well as on DR5G reporters, the RAR and RXR heterodimeric partners appear to activate independently in an additive manner, while the AF-2 of RAR may be preferentially responsible for the activity of the heterodimer on DR5T reporters (note that this accounts for the complete repression by RARdn mutants which was observed in experiments reported in Figure 2).

The above experiments did not exclude that a transcriptionally active RAR would be required for the AF-2 of RXR to be active on a DR5T element. To investigate this possibility, activation of DR5T-tk/CAT by HeLa cell endogenous RARs and RXRs was tested in the presence of either a specific RXR ligand (SR11237; Lehmann et al., 1992), T-RA, 9C-RA or T-RA, together with SR 11237 (Figure 7E). As expected from the above results, no activation was seen in the presence of SR11237, while DR5T-tk/CAT expression was induced by T-RA $(50 \mathrm{nM})$ addition (Figure 7E, lanes 2 and 3 ). However, the simultaneous addition of SR 11237 and T-RA resulted in a stronger activation, similar to that achieved with 9C-RA (Figure 7E, lanes 4 and 5). Under similar conditions DR5G-tk/ CAT, as well as DR1T-tk/CAT (data not shown), were efficiently activated by the RXR-specific ligand (Figure $7 \mathrm{E}$, lane 7) and, as expected from the results shown in Figure $7 \mathrm{~A}$ and $\mathrm{C}$, these activations were additive with those induced by T-RA (Figure 7E, compare lanes 7 and 8 with lanes 9 and 10). These results confirm that the AF-2s of RAR/RXR heterodimers bound to DR I and DR5G elements activate independently and additively, and most interestingly reveal that on DR5T elements the presence of a transcriptionally active RAR partner is required for the AF- 2 of the RXR partner to participate in activation of transcription.

\section{Discussion}

\section{An autonomous constitutive AF-2 activating domain and ligand dependency of AF-2}

We have identified here a motif located in the C-terminal part of the E region (boxed in Figure 1) whose integrity is required for the activity of the AF-2 of RAR $\alpha$ or RXR $\alpha$. Mutagenesis in this motif, which is highly conserved in many members of the nuclear receptor family (Figure 3D and E), can selectively abrogate AF-2 activity without significantly altering DNA binding, heterodimerization and T-RA binding by RAR $\alpha$. Interestingly, the corresponding motif is absent in v-erbA which has no AF-2 activity (Zenke et al., 1990; Saatcioglu et al., 1993); point mutagenesis of the hydrophobic or charged residues of this motif in ER and GR (Figure 3D) reduces AF-2 activity, but has little effect on steroid or DNA binding (Danielan et al., 1992). The use of chimeric receptors in which the RAR $\alpha$ motif was replaced by the corresponding motif of $\operatorname{TR} \alpha$ or RXR $\alpha$ (Figures 1 and 3) actually demonstrates that these motifs (which have the potential to form an amphipathic $\alpha$-helical structure; Zenke et al., 1990) are functionally interchangeable. Considering the first hydrophobic amino acid residue (L409 in the case of mRAR $\alpha 1$ ) as position 1 of the helix, an acidic residue is present at position 4 in many members of the nuclear receptor superfamily (Figure 3D), while another acidic residue is frequently found at position 7. In fact, both Glu412 and Glu415 appear to be required for optimal RAR $\alpha$ AF-2 activity, and mutagenesis of both of them to glutamine abrogates this activity. Peptides containing the above amphipathic helix can autonomously transactivate in both animal and yeast cells (Figure 6D-F), indicating that this helix is an activating domain of AF-2. This conclusion is strongly supported (i) by the observation that mutating the conserved Glu residues in these peptides abrogates their activation function (Figure 6D and E), and (ii) by Barettino et al. (1994) who have reported after completion of the present paper that the same region of the thyroid hormone receptor also possesses an autonomous activation domain.

Transcriptional activators appear to interact with basal transcription factors, TBP-associated factors (TAFs) or transcriptional intermediary factors (TIFs) to stimulate gene transcription (Tasset et al., 1990; Tjian and Maniatis, 1994, and references therein). Replacing a Glu by an Asp in AF-2 activating domain [compare $\alpha$ ARP-1(D412E) and $\alpha$ ARP-1(405-415); Figure 1] greatly decreases transactivation, strongly arguing for a mechanism whereby the activity of AF-2 is transduced through protein interactions involving specific interfaces. It also indicates that the AF-2 activating domain motif is distinct from other acidic 'VP16-like' activating domains (Cress and Triezenberg, 1991), in agreement with our previous squelching data (Tasset et al., 1990).

The presence of an autonomous transcriptional activity in RAR and RXR AF-2 activating domains raises the question as to why the activity of AF-2 is dependent on ligand binding and abrogated in mutants (e.g. $\alpha 301 \mathrm{R}$ ) unable to bind T-RA. When embedded in region $\mathrm{E}$, the AF-2 activating domain helix may either be in a transcriptionally active form but masked in some way, or exist in a 'deformed' inactive form. The ligand might be required to induce a conformational change in region $\mathrm{E}$ which would either unmask or generate an active AF-2 activating domain. In this respect, we note that binding of the ligand has been shown to induce conformational changes in several nuclear receptors (e.g. Keidel et al., 1994; Tate et al., 1994). The hypothesis that an otherwise 
active AF-2 activating domain is unmasked seems the more likely, since it does not appear that induction by the ligand requires a precise match between the ligand binding domain and AF-2 activating domain; indeed, RAR $\alpha$ chimeric receptors in which the RAR AF-2 activating domain has been replaced by that of a heterologous receptor (cTR $\alpha$ or mutated ARP-1) are efficiently activated by T-RA (Figure 1). The fact that the chimeric receptor $\alpha A R P-1(D 412 E)$ is readily inducible by T-RA also indicates that the binding pocket for T-RA is largely independent of the AF- 2 activating domain. This conclusion is in agreement with the finding (Tate et al., 1994) that RAR $\alpha$ sequences C-terminal to amino acid 404 are not required for efficient binding of T-RA (see also our mutant $\alpha \Delta 408-416$ in Figure 1); note also that the identity of the amino acids located C-terminal to position 404 are unlikely to be crucial for the binding of 9C-RA, since $\alpha$ T409TR $\alpha(402-407)$ and $\alpha$ ARP-1(D412E) were both stimulated by T-RA and 9C-RA (Figure 1 and data not shown). The inability of mutations D398E and L401E to generate an activator in the context of the full-length ARP-1 (Figure 1) may then reflect either the requirement for a putative ARP-1 ligand or the absence of a ligand binding domain in the COUP-TF family. Thus, the ARP-1(D398E,L401E) protein (and similar proteins for other orphan receptors; see below) could be used in searches for putative cognate ligands.

In the case of steroid receptors, ligand binding may result in (i) release of the heat shock protein hsp90 which may preclude efficient DNA binding (reviewed in Pratt and Welsh, 1994), and (ii) induction of AF-2 activity (Green and Chambon, 1988). This dual role is strongly supported by the fact that the oestrogen antagonist, tamoxifen, can efficiently promote DNA binding of the ER in animal and yeast cells, but not induction of AF-2 activity (Berry et al., 1990; Metzger et al., 1992). Since AF-2 activating domains of RAR and RXR are inactive within the unliganded $E$ region, even though these receptors are not associated with hsp90 (Dalman et al., 1991), we propose that the second strictly agonist-dependent activation step of steroid receptor corresponds to a conformational change similar to that which is necessary to expose an active RAR AF-2 activating domain. This conformational change would not be achieved by steroid antagonists functionally similar to tamoxifen which, however, would induce the structural transition required for hsp90 dissociation.

\section{Are all orphan receptors possible ligand-inducible activators?}

Orphan receptors are members of the nuclear receptor superfamily which have not yet been matched with any ligand (Laudet et al., 1992; O'Malley and Conneely, 1992). C-terminal sequence comparisons show that, in addition to the members of the COUP-TF family (see Introduction), a number of other orphan receptors [e.g. nur 77/NGFI-B/N10, hTR2, EAR-1/rev-erbA, and several Drosophila proteins like tailless (dTll), seven up (dSvp) and E75] completely lack the conserved motif, lack an acidic residue at position 4 of the motif or possess an Asp instead of a Glu residue at this position (Figure 3D). Interestingly, most of the orphan receptors which possess an Asp at position 4 may belong to a family which may have evolved from NGFI-B as a common ancestor (Laudet et al., 1992). Our results indicate that even if they would bind ligands not yet discovered, all of the AF-2 activating domain-lacking orphan receptors would most probably lack an activation function similar to the present AF-2s. Thus, these orphan receptors may either prevent activation by other ligand-inducible receptors (e.g. the members of the COUP-TF/ARP-1 family which bind promiscuously to a variety of REs) or transactivate through a constitutive AF-1 located in the A/B region (e.g. NGF1-B; Paulsen et al., 1992; Davis et al., 1993; Yoon and Lau, 1993). In contrast, orphan receptors which contain an AF-2 activating domain-like amphipathic $\alpha$-helix in their $E$ region may well possess AF-2s inducible by ligands which remain to be discovered.

The Fushi tarazu type 1 (FTZ-F1) family includes Drosophila FTZ-F1 $\alpha$ (Lavorgna et al., 1991), mouse steroidogenic factor 1 (mSF-1) and its splice variant mELP, bovine Ad4 binding protein (bAd4BP), Drosophila melanogaster hormone receptor 39 (DHR39, also called FTZ-F1 $\beta$ ), Xenopus FTZ-F1-related receptor 1 (xFF1rA) and $x F F 1 r B$ and their mouse homologue liver receptor homologous protein 1 (mLRH1; Figure 3E; Segraves, 1994, and references therein). Most of these receptors contain a Glu residue at position 4 of the conserved motif, with the exception of dFTZ-F1 $\alpha$ and mELP which completely lack this motif. Interestingly, mSF-1 and mELP, which are derived from the same gene by alternative splicing, have been shown to be a constitutive transactivator (mSF-1, which possesses an AF-2 activating domain) and a constitutive repressor (mELP, which lacks an AF-2 activating domain; Ikeda et al., 1993). This observation, together with the observation that XFF1rA and bAd4BP behave as activators (Ellinger-Ziegelbauer et al., 1994, and references therein), support the notion that the AF-2 activating domain is critical for the function of all members of the nuclear receptor family which act as activators. Moreover, changing an activator into a repressor by elimination of the AF-2 activating domain through a splicing event (as in the case of mELP) offers a simple mechanism to control, either positively or negatively, the expression of the same set of target genes.

\section{Different class of dominant negative receptors}

In the light of our results, dominant negative receptors can be classified into two groups: (i) potent dominant negative receptors which have lost their transactivation capacity but have kept their DNA binding and heterodimerization functions intact, and (ii) weak dominant negative receptors which have lost their DNA binding ability.

Potent dominant negative receptors, which have silent AF-2s and compete in a molar ratio with wild-type receptors for DNA binding upon heterodimerization, can be divided further. Receptors belonging to a first class have lost their AF-2 activating domain, by either deletion (e.g. RAC-65 and v-erbA; Saatcioglu et al., 1993) or point mutation (our point mutants and various dominant negative forms of RXR, TR or ER which are mutated in or near the AF-2 activating domain; Danielan et al., 1992; Ince et al., 1993; Refetoff et al., 1993; Tate et al., 1994). Potent dominant negative receptors of the second class 
have lost the capacity to bind their ligand which prevents activation of their AF-2 activating domain [e.g. our $\alpha 301 \mathrm{R}$ mutant and TR $\alpha 2$ (an isoform of TR $\alpha$; Lazar, 1993, and references therein)]. A third class of dominant negative mutant receptors might possibly exist which would be mutated in amino acids involved in the ligand-induced conformational change necessary to activate the AF-2 activating domain (see above).

A second group of dominant negative RAR mutants, which decreased transactivation mediated by the endogenous receptor only when produced at high concentration (e.g. $\alpha \mathrm{M} 1$ and $\alpha \mathrm{TM} 1$; Figure 4D), is similar to other dominant negative receptors which are active only at high concentrations and do not bind DNA (Wang et al., 1991; Bigler et al., 1992; Barettino et al., 1993). We propose that dominant negative receptors belonging to this second group act by heterodimerizing in solution with RXR (Nagpal et al., 1993), preventing it heterodimerizing with RAR (see also Barettino et al., 1993). Transcriptional squelching is unlikely to provide an alternative inhibitory mechanism, since AF-2 activity is abrogated in our $\alpha \mathrm{TM}$ RAR mutants. Thus, natural isoforms of TR (Bigler et al., 1992; Barettino et al., 1993; Lazar, 1993), RAR $\alpha, \beta$ and $\gamma$ (Kastner et al., 1990; Leroy et al., 1991; Zelent et al., 1991) and ER (Wang et al., 1991), which all cannot bind to DNA, could possibly participate in the control of the transcriptional activity of nuclear receptors through sequestration of a dimeric partner.

\section{The nature of the response element influences the activity of the AF-2s of RAR and RXR \\ heterodimeric partners}

Using various reporter genes containing RAREs of either DR1T, DR1G or DR5G and RAR/RXRdn or RARdn/RXR combinations, we have shown here that transcriptional activation results from the additive effect of the AF-2 activities of the RAR and RXR heterodimeric partners, acting independently irrespective of the promoter context. This conclusion, which was confirmed by using an RXRspecific ligand, is in agreement with our previous observations which indicated similar additive effects for activation mediated by either the DR1 or the DR2 RAREs of the mouse CRABPII gene (Durand et al., 1992). In contrast, using reporter genes containing a DR5T-type RARE (e.g. that of the RAR $\beta 2$ gene) and the same RAR/RXRdn and RARdn/RXR combinations, transactivation appears to result only from the AF-2 of the RAR heterodimeric partner, RXR behaving as a silent (non-activating) partner irrespective of the promoter context. Most interestingly, the use of an RXR-specific ligand revealed that in fact activation by the AF- 2 of RXR requires the presence of a transcriptionally active RAR partner. Our results also show that the AF-2 activity of the RAR partner of RAR/ RXRdn heterodimers bound to either a DR1T, DR1G or DR5G-type RARE was similarly induced by T-RA and 9C-RA, whereas 9C-RA was twice as efficient as T-RA at activating the RAR AF-2 when the heterodimers were bound to a DR5T-type RARE.

Since the above differential effects are independent of the precise nature of the responsive promoters, it is likely that they result from conformational modifications of the heterodimers which depend on the nature (sequence and spacing of the repeated motifs) of the DR elements. As a strong dimerization function, the ligand binding domain and the AF-2 overlap in RAR and RXR regions E (Leid et al., 1992a,b); binding to different RAREs may result in modifications of ligand binding and/or AF-2 activity. Such a possibility is supported by the observation that the Drosophila ecdysone nuclear receptor (EcR) cannot bind its cognate ligand unless heterodimerized with ultraspiracle (usp), the Drosophila RXR homologue (Yao et al., 1993; D.Hogness, personal communication). When compared with RAR/RXR heterodimers bound to DR1, DR2 or DR5G elements, the binding of RXR/RAR heterodimers to DR5T elements may change both the conformation of the $\mathrm{E}$ region (resulting in a silent RXR AF-2 in the absence of a transcriptionally active RAR partner) and the relative efficiency of T-RA and 9C-RA at inducing the AF-2 activity of the RAR partner (9C-RA being more efficient than T-RA). In this respect, note that the RAR binding pocket for 9C-RA may be partly different from that for T-RA (Tate et al., 1994). In any event, and irrespective of the possible underlying mechanism, our data clearly establish that the activity of the AF-2s of RXR/RAR heterodimers and their ligand response can vary depending on the nature of the response elements, irrespective of the context of the activated promoter. We have reported previously that the activity of the AF-2s of the different RARs and RXRs are promoter contextdependent (Nagpal et al., 1992, 1993). Thus, the transcriptional activity of a given heterodimeric combination of $\operatorname{RAR}(\alpha, \beta$ or $\gamma)$ and $\operatorname{RXR}(\alpha, \beta$ or $\gamma)$ appears to be dependent on the nature of both the bound RARE and the factors which are bound to the responsive promoter. This further expands the combinatorial possibilities (reviewed in Leid et al., 1992a; Chambon, 1994) which are necessary to generate the highly pleiotropic effects of the simple retinoid signal.

\section{Materials and methods}

\section{Construction of receptor mutants}

The C-terminal truncations of mRAR $\alpha 1$ ( $\alpha \mathrm{T}$ mutants) were constructed by exchanging the $E c o \mathrm{RV}-B a m \mathrm{HI}$ fragment of the mRAR $\alpha 1$ expression vector (encoding amino acids 267-462) with EcoRV-BamHI- or EcoRV-BgllI-digested PCR-amplified fragments corresponding to mRAR $\alpha 1$ (encoding amino acid 267 to the chosen C-terminal amino acid). $\alpha$ T409TR $\alpha(402-407)$ was similarly constructed using a $3^{\prime}$ PCR primer containing antisense information for mRAR $\alpha 1$ amino acids 404409 , for the TR amino acids FLEVFE and for a stop codon. $\alpha \Delta 408$ 416, $\alpha 412 \mathrm{P}, \alpha \mathrm{Q}-\mathrm{Q}(412,415), \alpha \mathrm{RXR} \alpha(405-415)$ and $\alpha \mathrm{ARP}-1(405-415)$ were constructed by double PCR amplification (Ho et al., 1989) to generate $E c o \mathrm{RV}-X m a \mathrm{I}$ or $E c o \mathrm{RV}-B g$ lII fragments containing the appropriate mutations. $\alpha \mathrm{Q}(412)$ and $\alpha \mathrm{Q}(415)$ were constructed by exchanging the EcoRV-BamHI fragment of the mRAR $\alpha 1$ expression vector, with $E c o \mathrm{RV}-B g l \mathrm{II}$-digested PCR fragments corresponding to $\alpha Q-Q(412-415)$ amplified using a 3' PCR primer encompassing the stop codon and $B g$ lII restriction site, and encoding the E412Q or E415Q substitutions. $\alpha$ ARP-1(R411Q), $\alpha$ ARP-1(D412E) and $\alpha$ ARP1(D412E,L415E) were similarly constructed using PCR fragments corresponding to $\alpha$ ARP-1(405-415) amplified using a $3^{\prime}$ oligonucleotide encompassing the stop and BglII restriction sites and encoding for respectively R411Q, D412E or D412E and L415E substitutions. ARP1(D398E,L401E) was constructed by a double PCR amplification procedure on an ARP-1 expression vector (gift from T.Lerouge) to generate a $B a m \mathrm{HI}-E c o \mathrm{RI}$ fragment containing the appropriate mutations. $\alpha \mathrm{Ml}$, $\alpha \mathrm{M} 2$ and $\alpha \mathrm{M} 3$ and the corresponding mutations in $\alpha \mathrm{T} 403$ ( $\alpha \mathrm{TM} 1$, $\alpha \mathrm{TM} 2$ and $\alpha \mathrm{TM} 3$ ), as well as $\alpha 301 \mathrm{R}$, were similarly constructed. PCRamplified fragments containing mutation M1 were cloned into KpnI-SstIdigested mRAR $\alpha 1$ or $\alpha \mathrm{T} 403$ expression vectors; PCR-amplified fragments containing mutations M2 and M3 were subcloned into mRAR $\alpha 1$ 
as $E c o \mathrm{RV}-\mathrm{XmaI}$ fragments and into $\alpha \mathrm{T} 403$ as $E c o \mathrm{RV}-\mathrm{BamHI}$ fragments. The $E c o \mathrm{RV}-X m a \mathrm{I} \mathrm{PCR}$-amplified fragment containing mutation G301R was subcloned into EcoRV-Xmal-digested mRAR $\alpha 1$. The Cterminal deletion mutants of $m R X R \alpha$, which are dominant negative mutations [mRXR $\alpha \mathrm{T} 1$ truncated at amino acid 454 and $\mathrm{mRXR} \alpha \mathrm{T} 2$ truncated at amino acid 448 (also referred to as mRXRdn)] were constructed by PCR amplification of $E c o \mathrm{RV}-B g / \mathrm{II}$ fragments encoding the new termination point and subcloned into $E c o \mathrm{RV}-B g$ III-digested $\mathrm{mRXR} \alpha$ expression vector (Leid et al., 1992b).

The chimeric protein Gal4-RAR $\alpha(404-418)_{3}$ was constructed by cloning a trimer of the oligonucleotide 5'-GTACGTCCATGCCACCGCTGATCCAGGAAATGCTGGAGAACTCTGAGC-3' in triplicate in the KpnI site of pG4M (Nagpal et al., 1993). The chimeric proteins ER(C)RAR (390-462) and ER(C)RXR(436-467) were created by cloning in pSG5 an EcoRI fragment encoding $5^{\prime}$ to $3^{\prime}$ the $\mathrm{F}$ region (residues 553-595), the DNA binding domain (residues 176-282) of the hER [ER(C)], the residues Pro-Gly-Gly and either amino acids 390-462 of mRAR $\alpha 1$ or $436-462$ of mRXR. ER(C)RAR $(-)$ was constructed by inserting the EcoRI fragment in the reverse orientation. ER(C) and $\mathrm{ER}(\mathrm{C}) \mathrm{RXR} \alpha(436-467)$ were also cloned into the EcoRI site of the yeast expression plasmids YEp90 (Pierrat et al., 1992).

The mRAR $\beta 2 / C A T$ reporter gene has been described previously (Smith et al., 1991), as well as DR1T-tk/CAT, DR1G-tk/CAT, DR5T-tk/ CAT and DR5G-tk/CAT (Mader et al., 1993a). DR5G-globin/CAT was generously provided by S.Kato. (ERE) $)_{2}$-tk/CAT was constructed by twice inserting an oligonucleotide corresponding to a consensus ERE into the Sall site of pBLCAT2 ${ }^{+}$. 17M5-G/CAT was derived from the $17 \mathrm{M} 2-\mathrm{G} / \mathrm{CAT}$ vector by inserting three additional $17 \mathrm{mer}$ repeats into the Bam HI site (Webster et al., 1988). The Saccharomyces cerevisiae reporter strains used were PL1 and PL3 (Pierrat et al., 1992).

Additional information and all oligonucleotide sequences are available upon request.

\section{Transient transfection of COS-1 cells, CAT expression analysis and gel retardation/shift assays}

COS-1 cell transfections, CAT assays and gel retardation/shift experiments were performed as described previously (Smith et al., 1991; Durand et al., 1992; Leid et al., 1992b).

Bacterial expression of RAR proteins and RA binding assays mRAR $\alpha 1, \alpha 301 R, \alpha \Delta 408-416$ and $\alpha 412 \mathrm{P}$ were each inserted into the Ncol-BamHI sites of pET3d (Novagen). Bacterial extracts containing the mRAR $\alpha 1$ or mutant mRAR $\alpha$ proteins were prepared as described previously (Leid et al., 1992b). Protein integrity was controlled by Western blot analysis (data not shown). The charcoal binding assay was used to determine RA binding of mRAR $\alpha 1$ and the selected mutants $\alpha 301 R, \alpha \Delta 408-416$ and $\alpha 412 \mathrm{P}$. A selected amount of [ ${ }^{3} \mathrm{H}$ ]RA (Dupont de Nemours) was dried so that the final ethanol concentration did not exceed $2 \%$, and mixed with $1 \mathrm{ml}$ of bacterial lysate/RA binding buffer mix [generally $1 \mu \mathrm{l}$ RAR-containing bacterial extract, $79 \mu$ ] BL21 $\left(D_{3}\right)$ plysS extract in $920 \mu \mathrm{l}$ of RA binding buffer $(0.12 \mathrm{M}$ $\mathrm{KCl}, 8 \mathrm{mM}$ Tris $-\mathrm{HCl} \mathrm{pH} 7.5,8 \%$ glycerol, $4 \mathrm{mM}$ DTT, $0.24 \mathrm{mM}$ phenylmethylsulfonyl fluoride)]. Determination of non-specific binding was performed by adding a 500-fold molar excess of unlabelled T-RA to the tritiated T-RA prior to the addition of bacterial extract. Incubation was carried out on ice for $16 \mathrm{~h}$ in the dark. $500 \mu \mathrm{l}$ of dextran-coated charcoal (3\% DCC, w/v) in G-P buffer $(150 \mathrm{mM} \mathrm{NaCl}, 100 \mathrm{mM}$ $\mathrm{Na}_{2} \mathrm{HPO}_{4}, 0.1 \%$ gelatin, $15 \mathrm{mM} \mathrm{NaN}$ ) were added, mixed and incubated on ice for $15 \mathrm{~min}$. Charcoal-absorbed RA was separated from receptorbound RA by centrifugation; RA in the supernatant was quantitated by scintillation counting. Analysis was performed according to Scatchard.

\section{Acknowledgements}

We are grateful to J.Grippo for the generous gift of 9C-RA and useful discussions. We thank H.Nakshatri, T.Lerouge, B.Le Douarin, B.O'Malley, S.Kato, P.Kastner and S.Nagpal for the generous gifts of plasmids; A.Pornon and S.Vicaire for technical help; F.Ruffenach and A.Staub for oligonucleotide synthesis; the cell culture staff for providing cells; and H.Gronemeyer and J.Clifford for critical reading of the manuscript and advice. We are very grateful to C.Werle, S.Metz, B.Boulay and J.M.Lafontaine for preparing the figures and to the secretarial staff for typing the manuscript. We regret that due to space limitation a number a valuable and useful references could not be cited here. All of them are available upon request. M.S. was supported by a long-term European Molecular Biology Organization fellowship and
C.G. by a ULP fellowship. This work was supported by funds from the Centre National de la Recherche Scientifique, the Institut National de la Santé et de la Recherche Médicale, the Centre Hospitalier Universitaire Régional, the Association pour la Recherche sur le Cancer, the Fondation pour la Recherche Médicale and the Human Frontier Science Program.

\section{References}

Au-Fliegner,M., Helmer,E., Casanova,J., Raaka,B.M. and Samuels,H.H. (1993) Mol. Cell. Biol., 13, 5725-5737.

Barettino,D., Bugge,T.H., Bartunek,P., Vivanco-Ruiz,M.dM., SonntagBuck,V., Beug,H., Zenke,M. and Stunnenberg,H.G. (1993) EMBO J., 12, 1343-1354.

Barettino,D., Vivanco-Ruiz,M. and Stunnenberg,H.G. (1994) EMBO J., 13, 3039-3049.

Berry,M., Metzger,D. and Chambon,P. (1990) EMBO J., 9, 2811-2818.

Bigler,J., Hokanson,W. and Eisenman,R.N. (1992) Mol. Cell. Biol., 12, 2406-2417.

Blomhoff,R.B. (1994) Vitamin A in Health and Disease. Marcel Dekker Inc., New York.

Chambon,P. (1994) Semin. Cell Biol., 5, 115-125.

Cooney,A.J., Leng,X., Tsai,S.Y., O'Malley,B. and Tsai,M.-J. (1993) J. Biol. Chem., 268, 4152-4160.

Cress,W.D. and Triezenberg.S.J. (1991) Science, 251, 87-90.

Dalman,F.C., Sturzenbecker,L.J., Levin,A.A., Lucas,D.A., Perdew,G.H., Petkovich,M., Chambon,P., Grippo,J.F. and Pratt,W.B. (1991) Biochemistry, 30, 5605-5608.

Damm,K., Heyman,R.A., Umesono,K. and Evans,R.M. (1993) Proc. Natl Acad. Sci. USA, 90, 2989-2993.

Danielan,P.S., White,R., Lees,J.A. and Parker,M.G. (1992) EMBO J., 11, 1025-1033.

Davis,I.J., Hazel,T.G., Chen,R.H., Blenis,J. and Lau,L.F. (1993) Mol. Endocrinol., 7, 953-964.

Durand,B., Saunders,M., Leroy,P., Leid,M. and Chambon,P. (1992) Cell, 71, 73-85.

Ellinger-Ziegelbauer,H., Hihi,A.K., Laudet,V., Keller,H., Wahli,W. and Dreyer,C. (1994) Mol. Cell. Biol., 14, 2786-2797.

Evans,R.M. (1988) Science, 240, 889-895.

Fawell,S.E., Lees,J.A., White.R. and Parker,M.G. (1990) Cell, 60, 953-962.

Forman,B.M. and Samuels,H.H. (1990) Mol. Endocrinol., 4, 1293-1301.

Freedman,L.P., Luisi,B.F., Korszun,Z.R., Basavappa,R., Sigler,P.B. and Yamamoto,K.R. (1988) Nature, 334, 543-546.

Giguère,V. (1994) Endocr. Rev., 15, 61-79.

Green,S. (1993) Nature, 361, 590-591.

Green,S. and Chambon,P. (1988) Trends Genet., 4, 309-314.

Gronemeyer,H. (1991) Annu. Rev. Genet., 25, 89-123.

Ho,S.N., Hunt,H.D., Horton,R.M., Pullen,J.K. and Pease,L.R. (1989) Gene, 77, 51-59.

Ikeda,Y., Lala,D.S., Luo,X., Kim,E., Moisan,M.P. and Parker,K.L. (1993) Mol. Endocrinol., 7, 852-860.

Ince,B.A., Zhuang,Y., Wrenn,C.K., Shapiro,D.J. and Katzenellenbogen, B.S. (1993) J. Biol. Chem., 268, 14026-14032.

Kastner,P., Krust,A., Mendelsohn,C., Garnier,J.M., Zelent,A., Leroy,P., Staub,A. and Chambon,P. (1990) Proc. Natl Acad. Sci. USA, 87, 2700-2704.

Kastner,P., Leid,M. and Chambon,P. (1994) In Blomhoff,R. (ed.), Vitamin $A$ in Health and Disease. Marcel Dekker Inc., New York, pp. 189-238.

Keidel,S., LeMotte,P. and Apfel,C. (1994) Mol. Cell. Biol., 14, 287-298.

Koelle,M.R., Talbot,W.S., Segraves,W.A., Bender,M.T., Cherbas,P. and Hogness,D.S. (1991) Cell, 67, 59-77.

Ladias,J.A.A., Hadzopoulou-Cladaras,M., Kardassi,D., Cardot,P., Cheng,J., Zannis,V. and Cladaras,C. (1992) J. Biol. Chem., 267, 15849-15860.

Laudet,V., Hänni,C., Coll.J., Catzeflis,F. and Stehelin,D. (1992) EMBO J., 11, 1003-1013.

Lavorgna,G., Ueda,H., Clos,J. and Wu,C. (1991) Science, 252, 848-851.

Lazar,M.A. (1993) Endocr. Rev., 14, 184-193.

Lehmann,J.M.. Jong,L., Fanjul,A., Cameron,J.F., Lu,X.P., Haefner,P., Dawson,M.I. and Pfahl,M. (1992) Science, 258, 1944-1946.

Leid,M., Kastner,P. and Chambon,P. (1992a) Trends Biochem. Sci., 17, 427-433.

Leid,M. et al. (1992b) Cell, 68, 377-395.

Leroy,P., Krust,A., Zelent,A., Mendelsohn,C., Garnier,J.-M., Kastner,P., Dierich,A. and Chambon,P. (1991) EMBO J., 10, 59-69.

Levin.A.A. et al. (1992) Nature, 355, 359-361 
Liu,Y., Yang,N. and Teng,C.T. (1993) Mol. Cell. Biol., 13, 1836-1846. Mader,S., Chen,J.-Y., Chen,Z., White,J., Chambon,P. and Gronemeyer,H. (1993a) EMBO J., 12, 5029-5041.

Mader,S., Leroy,P., Chen,J.-Y. and Chambon,P. (1993b) J. Biol. Chem., 268, 591-600.

Mangelsdorf,D.J., Umesono,K. and Evans,R.M. (1994) In Sporn,M.B., Roberts,A.B. and Goodman,D.S. (eds), The Retinoids. Raven Press Ltd, New York, pp. 319-349.

Metzger,D., Losson,R., Bornert,J.M., Lemoine,Y. and Chambon,P. (1992) Nucleic Acids Res., 20, 2813-2817.

Mietus-Snyter,M., Sladek,F.M., Ginsburg,G.S., Kuo,C.F., Ladias,J.A.A., Darnell,J.E.,Jr and Karathanasis,S.K. (1992) Mol. Cell. Biol., 12, 1708-1718.

Miyajima,N., Kadowaki,Y., Fukushige,S., Shimizu,S., Semba,K., Yamanashi,Y., Matsubara,K., Toyoshima,K. and Yamamoto,T. (1988) Nucleic Acids Res., 16, 11057-11074.

Miyata,K.S., Zhang,B., Marcus,S.L., Capone,J.P. and Rachubinski,R.A. (1993) J. Biol. Chem., 268, 19169-19172.

Nagpal,S., Saunders,M., Kastner,P., Durand,B., Nakshatri,H. and Chambon,P. (1992) Cell, 70, 1007-1019.

Nagpal,S., Friant,S., Nakshatri,H. and Chambon,P. (1993) EMBO J., 12 2349-2360.

Nakshatri,H. and Chambon,P. (1994) J. Biol. Chem., 269, 890-902.

O’Malley,B.W. and Conneely,O.M. (1992) Mol. Endocrinol., 6, 13591361.

Paulsen,R.E., Weaver,C.A., Fahrner,T.J. and Milbrandt,J. (1992) J. Biol. Chem., 267, 16491-16496.

Petkovich,M. (1992) Annu. Rev. Nutr., 12, 443-471.

Pierrat,B., Heery,D.M., Lemoine,Y. and Losson,R. (1992) Gene, 119, 237-245.

Pratt,W.B. and Welsh,M.J. (1994) Semin. Cell Biol., 5, 83-93.

Pratt,M.A.C., Kralova,J. and McBurney,M.W. (1990) Mol. Cell. Biol., 10, 6445-6453.

Refetoff,S., Weiss,R.E. and Usala,S.J. (1993) Endocr. Rev., 14, 348-399.

Saatcioglu,F., Bartunek,P., Deng,T., Zenke,M. and Karin,M. (1993) Mol. Cell. Biol., 13, 3675-3685.

Segraves,W.A. (1994) Semin. Cell Biol., 5, 105-113.

Smith,W.C., Nakshatri,H., Leroy,P., Rees,J. and Chambon,P. (1991) EMBO J., 10, 2223-2230.

Sporn,M.B., Roberts,A.B. and Goodman,D.S. (1994) The Retinoids. 2nd edn, Raven Press Ltd, New York.

Stunnenberg,H.G. (1993) BioEssays, 15, 309-315.

Tasset,D., Tora,L., Fromental,C., Scheer,E. and Chambon,P. (1990) Cell, 62, 1177-1187.

Tate,B.F., Allenby,G., Janocha,R., Kazmer,S., Speck,J., Sturzenbecker, L.J., Abarzua,P., Levin,A.A. and Grippo,J. (1994) Mol. Cell. Biol., 14, 2323-2330.

Tjian,R. and Maniatis,T. (1994) Cell, 7, 5-8.

Tran,P., Zhang,X.K., Salbert,G., Hermann,T., Lehmann,J.M. and Pfahl,M. (1992) Mol. Cell. Biol., 12, 4666-4676.

Wang,L.-H., Ing,N.H., Tsai,S.Y., O’Malley,B.W. and Tsai,M.J. (1991) Gene Expr., 1, 207-216.

Webster,N.J.G., Green,S., Tasset,D., Ponglikitmongkol,M. and Chambon,P. (1988) EMBO J., 8, 1441-1446.

Widom,R.L., Rhee,M. and Karathanasis,S.K. (1992) Mol. Cell. Biol., $12,3380-3389$.

Yao,T.P., Forman,B.M., Jiang,Z., Cherbas,L., Chen,J.D., McKeown,M., Cherbas,P. and Evans,R. (1993) Nature, 366, 476-479.

Yoon,J.K. and Lau,L.F. (1993) J. Biol. Chem., 268, 9148-9155.

Yu,V.C. et al. (1991) Cell, 67, 1251-1266.

Zechel,C., Shen,X.Q., Chen,J.Y., Chen,Z.P., Chambon,P. and Gronemeyer,H. (1994) EMBO J., 13, 1425-1433.

Zelent,A., Mendelsohn,C., Kastner,P., Garnier,J.-M., Ruffenach,F., Leroy,P. and Chambon,P. (1991) EMBO J., 10, 71-81.

Zenke,M., Munoz,A., Sap,J., Vennström,B. and Beug,H. (1990) Cell, 61, 1035-1049.

Received on July 28, 1994; revised on August 25, 1994 